\title{
OBERON3 and SUPPRESSOR OF MAX2 1-LIKE proteins form a regulatory module specifying phloem identity
}

Eva-Sophie Wallner ${ }^{1,3}$, Nina Tonn ${ }^{1}$, Friederike Wanke ${ }^{2}$, Vadir Lopéz-Salmerón ${ }^{1,4}$, Michael Gebert $^{1}$, Christian Wenzl ${ }^{1}$, Jan U. Lohmann ${ }^{1}$, Klaus Harter $^{2}$, Thomas Greb ${ }^{1 *}$

${ }^{1}$ Centre for Organismal Studies (COS), Heidelberg University, 69120 Heidelberg, Germany

${ }^{2}$ Center for Plant Molecular Biology (ZMBP), University of Tübingen, 72076 Tübingen, Germany

${ }^{3}$ Current address: Gilbert Biological Sciences, Stanford University, Stanford, CA 94305-5020, USA

${ }^{4}$ Current address: BD Bioscience, 69126 Heidelberg, Germany

${ }^{*}$ Corresponding author. Tel.: +49 622154 5524; Fax: +49 622154 6424; Email:

thomas.greb@cos.uni-heidelberg.de 


\section{Abstract}

The phloem tissue mediates long-distance transport of energy metabolites along plant bodies and, therefore, is central for plant performance. However, mechanisms initiating the transition of undifferentiated stem cells to cells specialized in metabolite transport are unknown. Here we identify the ubiquitously expressed PHD-finger protein OBERON3 (OBE3) to be essential for phloem formation. We show that OBE3 directly interacts with the SUPPRESSOR OF MAX2 1-LIKE 5 (SMXL5) protein specifically expressed during early phloem development. Both proteins co-localize in nuclei of phloem stem cells and, together with the SMXL5 homologs SMXL3 and SMXL4, promote the establishment of phloem-specific cellular signatures in a cellautonomous manner. These signatures include expression of OCTOPUS (OPS), BREVIS RADIX (BRX), BARELY ANY MERISTEM3 (BAM3), and COTYLEDON VASCULAR PATTERN2 (CVP2) genes acting as mediators of phloem differentiation. Consistently, genetic analyses show that SMXL5 acts upstream and independently of OPS and BRX functions. Based on our findings, we conclude that the formation of an OBE3/SMXL5 protein complex specifically in nuclei of early phloem cells is essential for establishing a phloem-specific developmental program.

Keywords: sieve element, Arabidopsis thaliana, root, stem cell 


\section{INTRODUCTION}

Growth and body shape of multicellular organisms largely depend on a functional longdistance transport of energy metabolites to fuel stem cell activity. In plants, sugars are photosynthetically produced in source organs, such as leaves, and delivered via the phloem to sink organs where they are allocated to storage tissues or stem cell niches, such as the root apical meristem (RAM) (Oparka and Turgeon 1999; De Schepper et al. 2013). The dividing stem cells of the RAM are located next to a mostly dormant organizer, known as quiescent center (QC) (van den Berg et al. 1997). These stem cells divide and differentiate in a strictly controlled manner to give rise to two phloem poles which ensure a steady energy supply to the RAM during root growth (Rodriguez-Villalon et al. 2014; Wallner et al. 2017). One phloem pole comprises a protophloem and a metaphloem strand, each forming a sieve element (SE) and a companion cell (CC) lineage (Lucas et al. 2013). During differentiation, SEs degrade most of their organelles to build connected sieve tubes for intracellular allocation of sugars, hormones, proteins and RNAs (Furuta et al. 2014). This is why functional SEs are metabolically sustained by CCs via intercellular channels named plasmodesmata (Ross-Elliott et al. 2017). Underlining the importance of the phloem, defects in protophloem development cause root growth defects, possibly, as a consequence of RAM starvation (Depuydt et al. 2013; Rodriguez-Villalon et al. 2014).

Due to the remarkable transition of phloem stem cells to cells holding an extreme degree of specialization, gaining insights into phloem formation and identifying its molecular regulators is highly instructive for our general understanding of cell fate regulation and differentiation. Moreover, due to the extreme importance of the phloem for plant growth and physiology, revealing mechanisms of phloem formation holds great promises for crop production and may increase our understanding of plant evolution and of the adaptation to environmental conditions. Importantly, although several genes, including OCTOPUS (OPS), 
PATTERN2 (CVP2), regulating different aspects of phloem formation have been characterized (Bonke et al. 2003; Depuydt et al. 2013; Rodriguez-Villalon et al. 2014; Anne et al. 2015; Rodriguez-Villalon et al. 2015; Hazak et al. 2017; Marhava et al. 2018), those genes seem to act downstream of phloem specification leaving the question open of how a phloem-specific developmental program is initiated.

Recently, a central role of the SUPPRESSOR OF MAX2 1-LIKE (SMXL) protein family members SMXL3, SMXL4 and SMXL5 in phloem formation was revealed (Wallner et al. 2017; Wu et al. 2017; Cho et al. 2018; Wallner et al. 2020). SMXL proteins are well-conserved nuclear localized developmental regulators and, in Arabidopsis thaliana (Arabidopsis), form a protein family of eight members sub-divided into different sub-clades based on phylogeny and function (Zhou et al. 2013; Soundappan et al. 2015; Liang et al. 2016; Wallner et al. 2016; Walker and Bennett 2017). While SMAX1 and SMXL2 are targeted for degradation by the karrikin signaling pathway to regulate germination and hypocotyl growth (Stanga et al. 2013; Stanga et al. 2016), SMXL6, SMXL7, and SMXL8 are proteolytic targets of strigolactone signaling, which is a hormonal pathway regulating shoot and root branching (Soundappan et al. 2015; Wang et al. 2015; Liang et al. 2016). In comparison, SMXL3/4/5 proteins act independently from both strigolactone and karrikin signaling as central regulators of phloem formation (Wallner et al. 2017). Their redundant and dose-dependent functions become obvious in double and triple mutants which are completely deprived of protophloem formation within the RAM resulting in root growth termination a few days after germination (Wallner et al. 2017). Despite their fundamental role in (proto)phloem formation the molecular mechanism of SMXL3/4/5 proteins remained obscure.

In contrast to SMXL proteins whose activity is spatially highly restricted, OBERONs (OBEs) are a family of four ubiquitously expressed, nuclear-localized proteins essential for tissue specification and meristem maintenance starting from the earliest stages of embryo 
development (Saiga et al. 2008; Thomas et al. 2009; Saiga et al. 2012; Lin et al. 2016). This role is reflected by mutants deficient for either of the two OBE sub-families which are embryo lethal (Saiga et al. 2008; Thomas et al. 2009; Saiga et al. 2012). In the shoot apical meristem (SAM), OBE3 (also known as TITANIA1 (TTA1)), interacts genetically with the homeobox transcription factor gene WUSCHEL (WUS) in stem cell regulation (Lin et al. 2016). Additionally, $O B E 1$ and $O B E 2$ are associated with vascular patterning in the embryo (Thomas et al. 2009). Interestingly, OBEs carry a highly conserved plant homeodomain (PHD)-finger domain known to bind di- and trimethylated histone $\mathrm{H} 3$ allowing recruitment of chromatin remodeling complexes and transcription factors (Sanchez and Zhou 2011). Indeed, OBE proteins show chromatin binding and remodeling activities important for root initiation during embryogenesis (Saiga et al. 2008; Saiga et al. 2012). Taken together, OBEs have versatile roles associated with cell fate regulation in plants (Saiga et al. 2008; Thomas et al. 2009; Saiga et al. 2012; Lin et al. 2016) but, as for SMXL proteins, their specific roles in distinct tissues and their mode of action is unknown.

Here, we report that OBE3 and SMXL5 proteins physically interact with each other forming a functional unit during protophloem formation in the RAM. Identified in a yeast twohybrid screen using SMXL5 as a bait, we provide evidence that SMXL5 and OBE3 proteins interact in yeast and in planta. We also elucidate a functional interaction between OBE3 and $S M X L 3 / 4 / 5$ genes during protophloem development in the root. Just like $S M X L 3 / 4 / 5, O B E 3$ is an essential component during protophloem initiation and differentiation. By characterizing the $S M X L 3 / 4 / 5-O B E 3$ interaction we provide insights into the molecular network of (proto)phloem formation in plants and propose that the $S M X L 3 / 4 / 5-O B E 3-d e p e n d e n t$ establishment of a distinct chromatin profile is an essential step during phloem specification. 


\section{RESULTS}

\section{Early phloem markers are less active in smxl4;smxl5 mutants}

To position the function of the SMXL4 and SMXL5 genes within the process of phloem formation, we introgressed a series of developmental markers visualizing early steps of phloem formation (Rodriguez-Villalon 2016) into the smxl4;smxl5 double mutant background. Although showing severe defects in protophloem formation, smx/4;smx/5 is viable and can be propagated in contrast to the $s m \times 13 ; s m \times 14 ; s m \times 15$ triple mutant, which is devoid of phloem tissues and seedling lethal (Wallner et al. 2017). Comparison of wild type and smx/4;smx/5 root tips two days after germination when the overall anatomy of the smx14;smx/5 RAM is not yet affected by phloem defects (Wallner et al. 2017), showed that OPS:OPS-GFP, BRX:BRXCITRINE, BAM3:BAM3-CITRINE, or CVP2:NLS-VENUS marker activities (Rodriguez-Villalon et al. 2014) were reduced or not detectable in smx/4;smx/5 plants (Figure 1, A-H). This reduction was found along the entire strand of the developing protophloem and included SEprocambium stem cells located immediately proximal to the quiescent center (QC). In these founder cells of the phloem tissuefounder cells, we observed accumulation of OPS-GFP and BRX-CITRINE fusion proteins in wild type which was hardly detectable in smx/4;smx/5 double mutants (Figure 1, I-P). In contrast to markers associated with early stages of phloem development, activity of the ALTERED PHLOEM DEVELOPMENT (APL) promoter marking differentiating SEs and CCs in wild type (Bonke et al. 2003) was not detectable in root tips of smxl4;smxl5 mutants (Supplementary Figure 1) similar to CALS7:H2B-YFP, a phloem differentiation marker tested previously (Wallner et al. 2017). These observations argued for an early role of SMXL4 and SMXL5 in establishing a general phloem-specific developmental program including OPS, BRX, BAM3, and CVP2 gene activities. 


\section{Early activity of SMXL genes upstream of OPS and BRX is required for phloem formation}

To challenge this conclusion, we tested the capacity of SMXL5 to restore protophloem formation when expressed under the control of promoters active during different phases of protophloem development (Rodriguez-Villalon 2016) by using root length as a fast and efficient read-out for phloem defects (Depuydt et al. 2013; Wallner et al. 2017). Supporting the need of SMXL5 activity during early phases of phloem development, reduced root length usually found in smxl4;smxl5 mutants was not observed when they expressed SMXL5 under the control of the early OPS, BAM3, or CVP2 promoters (Figure 2A, Supplementary Figure 1). Moreover, SE formation was restored in these backgrounds (Supplementary Figure 1). In contrast, driving SMXL5 expression by the APL promoter did not lead to restoration of root length or SE formation (Figure 2A, Supplementary Figure 1). These results showed that the SMXL5 function mediated by residual activity of early phloem-related promoters in smx/4;smx/5 mutants is sufficient to stabilize phloem development.

To see whether the reduced activity of regulators like $B R X$ is causative for reduced root length of $s m x|4 ; s m x| 5$ double mutants, we expressed BRX-VENUS in smx/4;smx/5 mutant backgrounds under the control of the early protophloem-specific SMXL4 promoter (Supplementary Figure 1F) (Wallner et al. 2017). Indeed, root length of SMXL4:BRXVENUS/smx/4;smx/5 lines was comparable to the length of wild type roots (Figure 2A) indicating that $B R X$ acts downstream of $S M X L 4$ and that reduced $B R X$ activity is one reason for disturbed phloem development in $s m x \mid 4 ; s m x / 5$ mutants. Further supporting a role of the SMXL4 and SMXL5 genes upstream of OPS, visualization of SMXL4 and SMXL5 proteins in OPS-deficient backgrounds by respective reporters (Wallner et al. 2017) did neither reveal a reduced level nor altered localization of SMXL4 or SMXL5 proteins in early protophloem cells (Figure 2, B-E). This suggested that in contrast to a positive effect of SMXL4 and SMXL5 on the activity of OPS and BRX genes (Figure 1), OPS was not important for stimulating SMXL4 or SMXL5 activity during early steps of phloem formation. 


\section{SMXL genes act on different steps of phloem formation than OPS and BRX}

To further test our interpretation that $S M X L$ genes on the one side and OPS and $B R X$ on the other side act on different steps of phloem development, we investigated their genetic interaction. The OPS protein is required for SE formation in the protophloem by counteracting the BAM3/CLAVATA3/ESR-related 45 (CLE45) pathway (Breda et al. 2019). Due to enhanced activity of the BAM3/CLE45 pathway, ops mutants develop 'gap cells' within protophloem strands in which SE establishment fails (Truernit et al. 2012; Rodriguez-Villalon et al. 2014). Interestingly, root length of ops;smx/5 double mutants was similarly reduced as in smx/4;smxl5 double mutants although smxl5 single mutants were not affected and ops single mutants were very variable in this regard (Figure $3 \mathrm{~A}$ ). This finding suggested an additive effect of the $S M X L$ and the OPS-dependent pathways on phloem formation. Indeed, when phloem development was carefully analyzed in the respective mutant backgrounds, we observed a variation of phloem defects in ops single mutants ranging from the appearance of gap cells to the complete absence of SEs in a small fraction of plants (Figure 3B, Supplementary Figure 2). In comparison, $60 \%$ of the ops;smx/5 mutants displayed complete SE deficiency demonstrating that both genes contribute to a robust phloem development. A similar trend was observed for brx;smxl5 double mutants. Like OPS, the BRX gene ensures continues SE formation in this case, however, by downregulation of $B A M 3$ transcription and steepening the auxin gradient in developing phloem cells (Scacchi et al. 2010; Depuydt et al. 2013; Marhava et al. 2018; Marhava et al. 2019). Similar to ops;smx/5 double mutants, brx;smx/5 double mutants developed shorter roots than brx and smxl5 single mutants and largely failed to differentiate SE (Figure 3A, Supplementary Figure 3). Importantly, in ops;smxl5 plants which developed SEs, gap cell formation was comparable to ops and brx single mutants (Figure 3B, Supplementary Figures 1). Together, these observations suggested that although all genes are important for a stable phloem formation, $S M X L$ genes and OPS and BRX genes regulate different steps during phloem formation. 


\section{SMXL5 proteins interact with OBE3 proteins in nuclei of plant cells}

To find indications for how SMXL proteins fulfil their role, we isolated interacting proteins by a Yeast-Two-Hybrid-based screen of a cDNA expression library generated from Arabidopsis seedlings. As a bait, we used the full length SMXL5 protein (Legrain et al. 2001; Cifuentes-Esquivel et al. 2013) and tested 84 million individual protein-protein interactions. As a result, we isolated 24 independent cDNA clones of the OBE3 gene. Interaction between SMXL5 and OBE3 proteins in yeast was confirmed when testing the interaction directly. Yeast colonies co-expressing BD-SMXL5 and AD-OBE3 protein fusions grew on high-stringency medium selecting for protein-protein interaction, while transformants expressing BD-SMXL5 or AD-OBE3 alone did not grow (Figure 4A) indicating that BD-SMXL5 and AD-OBE3 proteins interacted in yeast.

To confirm protein-protein interaction, we transiently expressed SMXL5 fused to a triple human influence hemagglutinin (HA) affinity tag and OBE3 fused to a six fold c-Myc epitope tag in Nicotiana benthamiana ( $N$. benthamiana) leaves under the control of the Cauliflower Mosaic Virus (CaMV) 35S promoter (Benfey and Chua 1990). In raw protein extracts before ('input') and after ('unbound') immunoprecipitation (IP) using HA-affinity beads and in the precipitate itself ('IP: $\alpha$ HA'), the SMXL5-3xHA protein was detected with the expected size of approximately $120 \mathrm{kDa}$ in Western analyses (Figure 4B). Importantly, the 6xMyc-OBE3 fusion protein co-immunoprecipitated with the SMXL5-3xHA protein and did not show unspecific binding to the HA-affinity beads, indicating that SMXL5-3xHA and 6xMyc-OBE3 proteins interacted in plant cells. Of note, the calculated size of $100 \mathrm{kDa}$ for the 6xMyc-OBE3 protein exceeded the expected size of approximately $92 \mathrm{kDa}$ suggesting that the 6xMyc-OBE3 protein is posttranslationally modified. 
To compare the sub-cellular localizations of SMXL5 and OBE3 proteins, we transiently expressed the SMXL5 protein fused to monomeric Cherry (SMXL5-mCherry) together with the OBE3 protein fused to monomeric GFP (OBE3-GFP) likewise in N. benthamiana leaves. Initially, nuclear localization of the OBE3 protein was confirmed by co-expressing OBE3-GFP with mCherry fused to a nuclear localization signal (mCherry-NLS). Interestingly, while the mCherry-NLS signal was homogenously distributed within the nucleus, the OBE3-GFP protein appeared in nuclear speckles (Figure 4, C-E). Co-expression of SMXL5-mCherry and OBE3GFP revealed a co-localization of both proteins within a sub-domain of the nucleus (Figure 4, F-H). This structure was clearly distinct from the whole nucleus highlighted by mGFP-mCherryNLS fusion protein expressed under the control of the ubiquitin 10 (UBI10) promoter (Figure $4, I-K)$

We next evaluated our yeast two-hybrid and co-immunoprecipitation data by performing Förster resonance energy transfer (FRET)-fluorescence lifetime imaging microscopy (FLIM) analysis as a cell biological assay for protein-protein association in transiently transformed $N$. benthamiana epidermal leaf cells. The FRET-FLIM analysis detected a significant change in the lifetime of the donor OBE3-mGFP fusions in the nucleus when co-expressed with SMXL5-mCherry (Figure 4L, M). In contrast, we did not observe significant mGFP lifetime changes when OBE-mGFP was expressed with NLS-mCherry (Figure 4L, M). Taken these observations together, we thus concluded that OBE3 interacts with SMXL5 in nuclei of living plant cells.

\section{The OBE3 gene acts together with SMXL3, SMXL4 and SMXL5}

Since physical interaction and subcellular co-localization suggested a common action of SMXL5 and OBE3 proteins in plants, we investigated whether the corresponding genes are functionally connected by using again root length as a first read-out for potential phloem defects. As before, $s m x \mid 4 ; s m x / 5$ double mutants were short rooted, while root lengths of $s m x / 4$ 
and smx/5 single mutants were similar to wild type (Wallner et al. 2017) (Figure 5, A and B). Similarly, roots from obe1, obe2, obe3 and obe 4 single mutants resembled wild type roots, while smxl4;obe3, smx/5;obe3 and smx/3;obe3 double mutants had short roots just as smx/4;smx/5 (Figure 5, A-D) suggesting a concerted action of OBE3 and SMXL3, SMXL4 or SMXL5 genes during primary root growth. Interestingly, we only detected a genetic interaction between SMXL3/4/5 and OBE3 and not between SMXL4/5 and the other OBE family members (Supplementary Figure 4).

\section{OBE3 locally promotes early stages of phloem development}

Because reduced root length of obe3;smxl double mutants suggested a role of $O B E$ genes in phloem development, we next tested whether $O B E$ genes are expressed in developing phloem cells by comparing the activity pattern of a translational SMXL4:SMXL4YFP reporter (Wallner et al. 2017) with patterns of translational OBE3:OBE3-GFP and OBE4:OBE4-GFP reporters (Saiga et al. 2012) (Figure 6, A-D). As a marker to identify protophloem cell lineages, we again used increased cell wall staining by Direct Red 23 based on the prominent cell walls of SE cells (Figure 6, A-C). As reported previously (Wallner et al. 2017), analysis of SMXL4:SMXL4-YFP reporter lines revealed SMXL4-YFP protein accumulation specifically in nuclei of developing protophloem cells (Figure 6A). In comparison, OBE3:OBE3-GFP and OBE4:OBE4-GFP reporters showed OBE3-GFP and OBE4-GFP protein accumulation in nuclei of all cell types of the root tip including developing protophloem cells (Figure 6, B-C). Considering that SMXL3 and SMXL5 proteins are also present in those cells (Wallner et al. 2017), we thus concluded that SMXL3/4/5 and OBE proteins had the potential to interact during early phloem formation. Of note, we could not detect differences in activity patterns between OBE3:OBE3-GFP and OBE4:OBE4-GFP reporters which argues against the fact that differences in expression are the reason why $O B E 3$, but not $O B E 4$, genetically interacted with $S M X L 3 / 4 / 5$ genes during root growth. 
To evaluate whether growth defects observed in smxl;obe3 roots are correlated with the same type of protophloem defects observed in smx/4;smx/5 mutants, we analyzed phloem development in the respective genetic backgrounds. During protophloem development, SE procambium-precursors divide tangentially to give rise to procambium and SE precursor cells. After 2-3 anticlinal divisions, SE precursor cells divide again tangentially to initiate meta- and protophloem cell files that subsequently undergo gradual differentiation (Figure 6D) (Wallner et al. 2017). Our analysis revealed that in obe3 mutant both the tangential cell divisions and the onset of SE differentiation appeared as in wild type roots (Figure 6, E, F, K). In contrast, in smx/4;obe3 and smx15;obe3 mutants, the onset of the second tangential division initiating meta- and protophloem cell lineages was similarly delayed as in smxl4;smx/5 mutants and the enhanced mPS-PI staining visualizing differentiated SEs was likewise absent (Figure 6 G-I, K and Supplementary Figure 5). This observation demonstrated that, like the more locally expressed $S M X L 3 / 4 / 5$ genes, OBE3 substantially contributes to phloem formation. Moreover, because respective single mutants did not show these defects (Figure 6 and Supplementary Figure 5), we concluded that OBE3 or SMXL5-deficient plants represent sensitized backgrounds for the functional loss of the other regulator. Of note, protophloem formation in smx15;obe4 double mutants was indistinguishable from wild type in accordance with the wild type-like root growth of those plants (Figure 6, E and J).

Because $O B E 3$ is broadly expressed, phloem defects observed in smx/5;obe3 mutants could arise due to a function of $O B E 3$ in other tissues than developing phloem cells, which would contradict a direct interaction of SMXL5 and OBE3 proteins. To address this concern and to determine whether $O B E 3$ acts cell-autonomously on phloem development, we expressed $O B E 3$ exclusively in developing phloem cells by introducing a transgene driving an OBE3-turquoise fusion protein under the control of the SMXL5 promoter (SMXL5:OBE3turquoise) into a smx/5;obe3 double mutant background. Microscopic analysis of root tips from smx15;obe3/SMXL5:OBE3-turquoise lines confirmed the presence of the OBE3-turquoise protein in nuclei of developing protophloem cells (Figure 7, A and B) as described for the 
SMXL5 protein expressed under the control of the same promoter (Wallner et al. 2017). When comparing smx/5;obe3/SMXL5:OBE3-turquoise lines with smx15;obe3 mutants, we observed that expression of OBE3-turquoise within the SMXL5 domain was indeed sufficient to restore root length in smx/5;obe3 double mutants (Figure 7, C and D). Additionally, enhanced counter staining in mature protophloem, which indicated that SE differentiation, was recovered in smx15;obe3 carrying the SMXL5:OBE3-turquoise transgene (Figure 7, A and B). To see whether the predominant reduction of $O B E 3$ activity is sufficient for generating phloem defects, we designed two independent artificial microRNAs targeting the OBE3 mRNA (obe3-miRNAs) (Schwab et al. 2006) which we expressed under the control of the SMXL5 promoter in smxI5 mutant plants. As expected, the majority of those plants was short rooted, indicating that $O B E 3$ knock-down within the SMXL5 domain was sufficient to evoke a smxl5;obe3-like phenotype in smx/5 mutants (Figure $7, \mathrm{C}$ and $\mathrm{D}$ ). We thus concluded that $O B E 3$ fulfils a local and cell autonomous role in protophloem formation. 


\section{DISCUSSION}

Cell type specification is fundamental for establishing multicellular organisms and, in recent years, the phloem has become an instructive model for studying this aspect in plants (Anne and Hardtke 2017; Blob et al. 2018). With our study we provide new insights into the regulation of (proto)phloem formation by revealing a role of the putative chromatin remodeling protein OBE3 (Saiga et al. 2012) and a direct interaction between the OBE3 protein and the central phloem regulator SMXL5. Based on our findings, we propose that SMXL proteins fulfil their role in phloem formation by establishing a distinct chromatin signature important for establishing phloem identity.

\section{SMXL3/4/5 and OBE3 proteins act together on early stages of phloem development}

SMXL3/4/5 and OBE3 proteins are already expressed in phloem stem cells (Wallner et al. 2017), which was so far not described for other phloem regulators (Blob et al. 2018). Unexpectedly, we detected OPS and BRX protein accumulation already in those stem cells raising the question of functional interdependance. The positive effect of SMXL4 and SMXL5 gene functions on OPS and BRX protein accumulation in those and more mature phloem cells suggests, however, that $S M X L$ genes are required for the establishment of a phloem-specific developmental program including OPS and BRX gene activities. The different subcellular localization of OPS, BRX and BAM3 proteins on the one side and SMXL proteins on the other side argues against a more interconnected function of both groups of regulators. The conclusion that both groups act on different aspects of phloem formation is furthermore supported by our genetic analyses which revealed a combination of distinct phloem defects in respective double mutants. Here, we propose that SMXL proteins fulfil their role in the nucleus of phloem stem cells and beyond by direct interaction with OBE3. In fact, the SMXL3/4/5-OBE3 interaction seems to be a prerequisite for both the initiation of phloem cell fate and a timely onset of differentiation. On the genetic level, smx/4;obe3, smx/5;obe3 and the smx/4;smx/5 double mutants share the same phloem defects meaning that they are deprived of protophloem 
formation within the RAM. Other reported phloem mutants have either problems with completing phloem differentiation in general, which is the case in mutants of the ALTERED PHLOEM DEVELOPMENT (APL) gene (Bonke et al. 2003; Truernit et al. 2008; Kondo et al. 2016), or they develop 'gap cells' in which SE-differentiation is disturbed as in ops or brx single or in cvp2;cvp2-like1 (cvl1) double mutants (Depuydt et al. 2013; Anne et al. 2015; RodriguezVillalon et al. 2015; Marhava et al. 2018; Breda et al. 2019). In contrast, smxl5;obe3, smx/4;obe3 and multiple mutants of the $S M X L 3 / 4 / 5$ genes show absence of all morphological hallmarks of phloem formation within the RAM. This suggests that SMXL3/4/5 and OBE3 act together on the establishment of a phloem-specific developmental program. Interestingly, complete suppression of protophloem formation was so far only reported for roots treated with certain CLAVATA3/ESP-RELATED (CLE) peptides, such as CLE45, which signal through the leucine-rich repeat receptor like kinase BAM3 and the pseudokinase CORYNE (CRN) (Depuydt et al. 2013; Hazak et al. 2017). Of note, the formation of 'gap cells' in ops or brx mutants is suppressed in BAM3-deficient backgrounds (Rodriguez-Villalon et al. 2014). This, on the one hand, indicates a molecular interplay between OPS/BRX and BAM3-CLE45, and, on the other hand, shows that none of those factors is required to obtain protophloem cell identity and proper differentiation in the first place (Depuydt et al. 2013; Rodriguez-Villalon et al. 2014). Future work will show how the SMXL3/4/5/OBE3 module interacts with these signaling components.

\section{A putative role of a SMXL3/4/5/OBE3 protein complex in chromatin remodeling}

PHD-finger motifs as carried by the OBE3 protein are known to be epigenetic readers binding to histone $\mathrm{H} 3$ tails carrying distinct post-translational modifications such as trimethylation of lysine $4(\mathrm{H} 3 \mathrm{~K} 4 \mathrm{me} 3)$ or lysine 9 (H3K9me) marking actively transcribed or silent chromatin regions, respectively (Sanchez and Zhou 2011). Although PHD finger proteins themselves are not necessarily activating or repressing, they can indirectly modify transcription by recruiting chromatin modifying complexes (De Lucia et al. 2008). Indeed, OBE proteins 
have been proposed to remodel chromatin structure during embryogenesis and thereby transcriptionally activate RAM initiation factors (Saiga et al. 2012). SMXL proteins share an ethylene-responsive element binding factor-associated amphiphilic repression (EAR) motif which interacts with transcriptional regulators of the TOPLESS (TPL) family (Pauwels et al. 2010). Indeed, the strigolactone signaling mediators SMXL6, SMXL7, SMXL8 and DWARF53 (D53), an SMXL protein from rice, directly interact with TPL-like proteins (Soundappan et al. 2015; Wang et al. 2015; Ma et al. 2017). TPLs are transcriptional co-repressor that can recruit histone deacetylases (HDAC) and, thereby, induce chromatin condensation and transcriptional suppression (Krogan and Long 2009; Ma et al. 2017). In addition to EAR motifs, SMXLs share a conserved double caseinolytic protease $(\mathrm{Clp})$ domain with ATPase activity that resembles heat shock protein 101 (HSP101) (Jiang et al. 2013; Zhou et al. 2013). As recently proposed, the p-loop ATPase domain of D53 fosters the formation of TPL hexamers and the threading of DNA through a central pore of this hexamer inducing nucleosome repositioning and/or higherorder chromatin reorganization (Ma et al. 2017).

Judging from the protein domains and sub-nuclear localization, we hypothesize that SMXL3/4/5 and OBE3 form a protein complex that is involved in chromatin remodeling and/or transcriptional regulation of downstream targets. Similar to the previous report on the OBE3WUS interaction in the SAM (Lin et al. 2016), we cannot rule out that other OBE family members apart from OBE3 interact with SMXL3/4/5 in protophloem formation. Although all mutant alleles used in this study were reported to be functional knock-outs because multiple mutants show strong embryonic defects (Saiga et al. 2008; Saiga et al. 2012), residual activity of the OBE1, OBE2 or OBE4 genes might be sufficient to support $S M X L 3 / 4 / 5$ activity. In summary, our study reveals the functional interaction between $S M X L 3 / 4 / 5$ and $O B E 3$, an important step in understanding the role of SMXL proteins in phloem formation. 


\section{Material and Methods}

\section{Arabidopsis thaliana}

Genotypes of plant species Arabidopsis thaliana (L.) Heynh. of the ecotype Columbia (Col) used for genetic analysis are listed in the Key Resource Table. Sterile seeds were stratified in microcentrifuge tubes containing $\mathrm{dH}_{2} \mathrm{O}$ at $4{ }^{\circ} \mathrm{C}$ in the dark for 3 days and then sown in rows on $1 / 2$ Murashige and Skoog (MS) medium-plates supplemented with $1 \%$ sucrose and grown vertically. Seedlings were grown in long day (LD, $16 \mathrm{~h}$ light and $8 \mathrm{~h}$ dark) conditions at $21^{\circ} \mathrm{C}$ for 2-10 days. Flowering plants were transformed by the floral dip method described earlier (Clough and Bent 1998). Seeds were liquid sterilized by $70 \%$ ethanol supplemented with $0.2 \%$ Tween-20 for $15 \mathrm{~min}$, washed twice with $100 \%$ ethanol and air dried under sterile conditions.

\section{Yeast-Two-Hybrid}

The yeast-based screen for proteins interacting with SMXL5 was performed by Hybrigenics (Evry, France) as described before (Legrain et al. 2001). The yeast strain AH109 was used for the yeast two-hybrid assay according to Matchmaker ${ }^{\mathrm{TM}}$ Two-Hybrid System 3 (Clontech, Palo Alto) and grown on YPD (full medium) or SD (selective medium)-agar plates for $3-5$ days at $28^{\circ} \mathrm{C}$, then stored at $4^{\circ} \mathrm{C}$ and stroked onto new plates every 10 days. Dilution series (OD600 1-0.001) of transformed yeast strains were grown for 3 days on selective medium (SD) -Leu/-Trp/-His/-Ade selecting for protein interaction or SD -Leu/-Trp selecting for the presence of the plasmids. When grown in liquid YPD medium for transformation, yeast was grown over night at $28^{\circ} \mathrm{C}$ with shaking at $250 \mathrm{rpm}$. For expressing the GAL4BD-SMXL5 fusion protein in yeast the open reading frame of the $S M X L 5$ gene was cloned into Xmal/BamHI sites of the $p G B K T 7$ plasmid (Clontech, Palo Alto) resulting in $p E W 6$. For expressing the GAL4ADOBE3 fusion protein, the open reading frame of the OBE3 gene was cloned into Xmal/BamHI sites of the $p G A D T 7$ plasmid (Clontech, Palo Alto) resulting into $p E W 11$. 


\section{Agrobacterium tumefaciens}

The Agrobacterium tumefaciens genotypes C58C1: RifR with pSoup plasmid (TetR) or ASE: KanR, CamR with pSoup+ plasmid (TetR) were used for transformation of Arabidopsis thaliana or infiltration of $N$. benthamiana leaves and grown at $28^{\circ} \mathrm{C}$ over night in liquid YEB medium on a shaker $\left(180 \mathrm{rpm}\right.$ to $\left.a \mathrm{OD}_{600}>1\right)$ or plated on YEB-plates and grown in an incubator (Fraley et al. 1983; Ashby et al. 1988; Hellens et al. 2000). Antibiotics were used for plasmid selection.

\section{Root length measurements}

For measuring root lengths, seedlings were scanned by a commercial scanner and analyzed using ImageJ 1.49d (Schindelin et al. 2012).

\section{Genotyping}

Genotyping was performed by PCR using primers listed in Supplementary Table 1. Further information about standard DNA extraction and genotyping can be found in (Wallner 2018).

\section{Transient protein expression in $N$. benthamiana}

$N$. benthamiana plants were used for transient protein expression and grown in the greenhouse at approximately $25^{\circ} \mathrm{C}$ and watered daily. Transformed Agrobacteria were stored as glycerol stocks and grown in a $10 \mathrm{ml}$ YEB liquid culture prior to use. The densely grown culture was centrifuged at $4000 \mathrm{rpm}$ for $5 \mathrm{~min}$ at RT. The supernatant was removed and the pellet was washed with $5 \mathrm{ml}$ induction buffer and re-suspended in $10 \mathrm{ml}$ induction buffer. Culture densities were adjusted to an $\mathrm{OD}_{600}$ of 1 . Prior to infiltration, these bacterial solutions 
were mixed with Agrobacteria expressing 35S:P19 in a ratio $1: 2$ and incubated in the dark for 2-3 h (Voinnet et al. 2003; Scholthof 2006). N. benthamiana leaves were infiltrated with the mixtures using a $1 \mathrm{ml}$ syringe (Becton Dickinson S.A., Heidelberg, Germany). Leaves were harvested three days after infiltration.

\section{Protein extraction, immunoprecipitation and Western blot}

Infiltrated $N$. benthamiana leaves were frozen in liquid nitrogen and ground by a mortar. Proteins were extracted by mixing the leaf powder $1: 1$ with extraction buffer $\left(50 \mathrm{mM} \mathrm{Na}_{3} \mathrm{PO}_{4}\right.$, $150 \mathrm{mM} \mathrm{NaCl}, 10 \%$ glycerol, $5 \mathrm{mM}$ EDTA, $10 \mathrm{mM} \beta$-mercaptoethanol, 0.1\% triton X-100, 2 $\mathrm{mM} \mathrm{NaVO}$, 2 mM NaF, $20 \mu \mathrm{M}$ MG-132, 1 mM PMSF, 1x cOmpleteTM Protease Inhibitor Cocktail (Roche; Basel, Switzerland)). Each sample was vortexed for $10 \mathrm{sec}$ and centrifuged at $13000 \mathrm{rpm}$ for $10 \mathrm{~min}$ at $4{ }^{\circ} \mathrm{C}$. The protein extract was retrieved by sieving it through a nylon mesh. Protein quantities were measured by Bradford assays according to the manual provided with the Bio-Rad Protein Assay Dye Reagent Concentrate (Bio-Rad Laboratories; Hercules, USA). Proteins were immunoprecipitated by $50 \mu \mathrm{l}$ Anti-HA MicroBeads (Miltenyi Biotec, Bergisch Gladbach, Germany) after incubation for $2.5 \mathrm{~h}$ at $4{ }^{\circ} \mathrm{C}$ while slowly rotating. Beads were captured by $\mu$ Columns (Miltenyi Biotec, Bergisch Gladbach, Germany) on magnetic stands by following the user manual and washed three times by $200 \mu$ Wash buffer I (extraction buffer without $\beta$-mercaptoethanol) and two times by $200 \mu \mathrm{l}$ Wash buffer II (50 mM $\mathrm{Na}_{3} \mathrm{PO}_{4}, 150 \mathrm{mM} \mathrm{NaCl}, 10 \%$ glycerol, $5 \mathrm{mM}$ EDTA). Proteins were eluted by 2x Laemmli buffer $\left(95^{\circ} \mathrm{C}\right)$ and separated by size on a SDS-PAGE with subsequent western blotting. Detailed procedures can be found in (Wallner 2018). SMXL5-3xHA and 6xMyc-OBE3 bands were detected by antibodies Anti-HA-Peroxidase High Affinity (3F10) (Roche; Basel, Switzerland) or c-Myc Antibody (9E10) sc-40 HRP (Santa Cruz Biotechnology, Santa Cruz, USA), respectively and visualized by chemiluminescence agents SuperSignal ${ }^{\mathrm{TM}}$ West Femto Maximum Sensitivity Substrate (Thermo-Scientific; Waltham, USA) by an Advanced Fluorescence and ECL Imager (Intas Science Imaging Instruments, Göttingen, Germany). 


\section{FRET-FLIM analyses}

FRET-FLIM analyses were performed principally as described previously (Ladwig et al. 2015; Arongaus et al. 2018). Briefly, measurements were performed using a Leica TCS SP8 microscope (Leica Microsystems, Germany) equipped with a rapidFLIM unit (PicoQuant). Images were acquired using a $63 x / 1.20$ water immersion objective. For the excitation and emission of fluorescent proteins, the following settings were used: mGFP at excitation $488 \mathrm{~nm}$ and emission 500-550 nm; and mCherry at excitation $561 \mathrm{~nm}$ and emission 600-650 nm. The lifetime $\mathrm{T}[\mathrm{ns}]$ of either the donor only expressing cells or the cells expressing the indicated combinations was measured with a pulsed laser at an excitation light source of $470 \mathrm{~nm}$ and a repetition rate of $40 \mathrm{MHz}$ (PicoQuant Sepia Multichannel Picosecond Diode Laser, PicoQuant Timeharp 260 TCSPC Module and Picosecond Event Timer). The acquisition was performed until 500 photons in the brightest pixel were reached. To obtain the GFP fluorescence lifetime, data processing was performed with SymPhoTime software and bi-exponential curve fitting and a correction for the instrument response function. Statistical analysis was carried out using the JMP 14 sofware (JMP, USA).

\section{Direct Red 23 staining}

To preserve fluorescent signals in roots, seedlings were fixed in a vacuum chamber for $1 \mathrm{~h}$ by $4 \%(\mathrm{w} / \mathrm{v})$ PFA dissolved in PBS. The tissue was washed twice by PBS and cleared with ClearSee solution for a minimum of two days according to (Kurihara et al. 2015). Cleared seedlings were stained by $0.01 \%$ (w/v) Direct Red 23 in ClearSee solution for $1 \mathrm{~h}$. Excess staining was removed by clearing once again in pure ClearSee solution for $1 \mathrm{~h}$.

\section{mPS-PI staining}

The mPS-PI staining of roots was carried out as described before (Truernit et al. 2008). 


\section{Confocal microscopy}

For confocal microscopy, TCS SP5 or SP8 microscopes (Leica Microsystems; Mannheim, Germany) were used. GFP signals were excited at excited by an argon laser at $488 \mathrm{~nm}$, collecting the emission between $500-575 \mathrm{~nm}$. YFP was excited by an argon laser at $514 \mathrm{~nm}$ and the emission detected in a range of 520-540 $\mathrm{nm}$. DirectRed stained tissue was excited at $561 \mathrm{~nm}$ (DPSS laser) and emission was detected at wavelengths $>660 \mathrm{~nm}$. mPS-PI stained tissue was excited at $561 \mathrm{~nm}$ (DPSS laser) and emission was detected at 590-690 nm.

\section{Molecular cloning and miRNA generation}

OPS:SMXL5-VENUS (pNT52), OPS:ER-VENUS (pNT53), BAM3:SMXL5-VENUS (pNT49), BAM3:ER-VENUS (pNT50), CVP2:SMXL5-VENUS (pNT16), CVP2:ER-VENUS (pNT69), APL:SMXL5-VENUS (pNT10), APL:ER-VENUS (pNT68), SMXL4:BRX-VENUS (pNT72), SMXL5:OBE3-turquoise (pEW72), 35S:5Xc-Myc-OBE3 (pEW78), 35S:SMXL5mCherry (pVL122), 35S:OBE3-mGFP (pVL127), 35S:mCherry-NLS (pMG103) and UBI10:mGFP-mCherry-NLS ( $p C W 194$ ) constructs were generated by using appropriate modules according to the GreenGate manual described in (Lampropoulos et al. 2013). Destination modules, entry modules, and correlating primers for amplifying DNA fragments for generating entry modules are depicted in Supplementary Table 1. In case reporter proteins were targeted to the endoplasmatic reticulum (ER), they were fused to the appropriate motifs (Haseloff et al. 1997). miRNAs targeting OBE3 transcripts were designed and cloned according to the manual provided by the WMD3 - Web MicroRNA Designer Version 3 (Max Planck Institute for Developmental Biology, Tübingen. http://www.weigelworld.org) with primers listed in Supplementary Table 1. To generate 35S:SMXL5-3XHA ( $p E W 33$ ), the SMXL5 CDS was amplified by primers listed In Supplementary Table 1 and cloned into BamHI/Xbal sites of pGreen0229:35S (Hellens et al. 2000) resulting in pKG33. Next, ssDNA sequences coding for $3 \mathrm{xHA}$ (Supplementary Table 1) were annealed by gradual cool-down from $80{ }^{\circ} \mathrm{C}$ to 
$50{ }^{\circ} \mathrm{C}$ and inserted into vector $p K G 33$ using BamHI/Xmal sites, resulting in plasmid $p E W 31$.

Further information about detailed cloning procedures can be found in (Wallner 2018).

\section{Quantification and statistical analyses}

Statistical analyses were performed using IBM SPSS Statistics for Windows, Version 22.0. Armonk, NY: IBM Corp or using GraphPad Prism version 6.01 (GraphPad Software, La Jolla, USA). Means were calculated from measurements with sample sizes as indicated in the respective figure legends. In general, all displayed data represents at least three independent, technical repetitions, unlike otherwise indicated. Error bars represent \pm standard deviation. All analyzed datasets were prior tested for homogeneity of variances by the Levene statistic. Oneway ANOVA was performed, using a confidence interval $(\mathrm{Cl})$ of $95 \%$ and a post-hoc Tukey HSD for comparisons of five or more data sets of homogenous variances or a post-hoc Tamhane-T2 in case variances were not homogenous. Graphs were generated in GraphPad Prism version 6.01 (GraphPad Software, La Jolla, USA) or in Excel (Microsoft, Redmond, USA). 


\section{Acknowledgements}

This work was supported by the SFB 1101 to K.H., J.U.L, and T.G. and SFB 873 to J.U.L. and T.G. (Deutsche Forschungsgemeinschaft, DFG), a Heisenberg Professorship (DFG, GR 2104/5-2), and an ERC Consolidator grant (PLANTSTEMS, \#647148) to T.G. and a PhD student fellowship of the Cusanuswerk to N.T.. We are grateful to Christian Hardtke (University of Lausanne, Switzerland), Dolf Weijers, Shunsuke Saiga (both at Wageningen University, The Netherlands), Andy Maule (John Innes Centre, UK), Sebastain Wolf and Karin Schumacher (both Heidelberg University, Germany) for providing seed material and constructs.

\section{Author Contributions}

Conceived and designed the experiments: EW, NT, FW, VL, KH, TG. Performed experiments: EW, NT, FW, VL, MG, CW, JUL. Analysed the data: EW, NT, FW, KH, TG. Wrote the paper: EW, TG.

\section{Conflict of Interest}

The authors declare that they have no conflict of interest. 


\section{References}

Anne P, Azzopardi M, Gissot L, Beaubiat S, Hematy K, Palauqui JC. 2015. OCTOPUS Negatively Regulates BIN2 to Control Phloem Differentiation in Arabidopsis thaliana. Current Biology 25: 2584-2590.

Anne P, Hardtke CS. 2017. Phloem function and development-biophysics meets genetics. Curr Opin Plant Biol 43: 22-28.

Arongaus AB, Chen S, Pireyre M, Glockner N, Galvao VC, Albert A, Winkler JB, Fankhauser C, Harter K, Ulm R. 2018. Arabidopsis RUP2 represses UVR8-mediated flowering in noninductive photoperiods. Genes Dev 32: 1332-1343.

Ashby AM, Watson MD, Loake GJ, Shaw CH. 1988. Ti plasmid-specified chemotaxis of Agrobacterium tumefaciens $\mathrm{C} 58 \mathrm{C} 1$ toward vir-inducing phenolic compounds and soluble factors from monocotyledonous and dicotyledonous plants. Journal of bacteriology 170: 4181-4187.

Benfey PN, Chua NH. 1990. The Cauliflower Mosaic Virus 35S Promoter: Combinatorial Regulation of Transcription in Plants. Science 250: 959-966.

Blob B, Heo JO, Helariutta Y. 2018. Phloem differentiation: an integrative model for cell specification. J Plant Res 131: 31-36.

Bonke M, Thitamadee S, Mähönen AP, Hauser MT, Helariutta Y. 2003. APL regulates vascular tissue identity in Arabidopsis. Nature 426: 181-186.

Breda AS, Hazak O, Schultz P, Anne P, Graeff M, Simon R, Hardtke CS. 2019. A Cellular Insulator against CLE45 Peptide Signaling. Current biology: CB 29: 2501-2508.

Cho H, Cho HS, Nam H, Jo H, Yoon J, Park C, Dang TVT, Kim E, Jeong J, Park S et al. 2018. Translational control of phloem development by RNA G-quadruplex-JULGI determines plant sink strength. Nature plants 4: 376-390.

Cifuentes-Esquivel N, Bou-Torrent J, Galstyan A, Gallemi M, Sessa G, Salla Martret M, RoigVillanova I, Ruberti I, Martinez-Garcia JF. 2013. The bHLH proteins BEE and BIM positively modulate the shade avoidance syndrome in Arabidopsis seedlings. The Plant journal : for cell and molecular biology 75: 989-1002.

Clough SJ, Bent AF. 1998. Floral dip: a simplified method for Agrobacterium-mediated transformation of Arabidopsis thaliana. The Plant journal : for cell and molecular biology 16: 735-743.

De Lucia F, Crevillen P, Jones AM, Greb T, Dean C. 2008. A PHD-polycomb repressive complex 2 triggers the epigenetic silencing of FLC during vernalization. Proceedings of the National Academy of Sciences of the United States of America 105: 1683116836.

De Schepper V, De Swaef T, Bauweraerts I, Steppe K. 2013. Phloem transport: a review of mechanisms and controls. Journal of experimental botany 64: 4839-4850.

Depuydt S, Rodriguez-Villalon A, Santuari L, Wyser-Rmili C, Ragni L, Hardtke CS. 2013. Suppression of Arabidopsis protophloem differentiation and root meristem growth by CLE45 requires the receptor-like kinase BAM3. Proceedings of the National Academy of Sciences of the United States of America 110: 7074-7079.

Fraley RT, Rogers SG, Horsch RB, Sanders PR, Flick JS, Adams SP, Bittner ML, Brand LA, Fink CL, Fry JS et al. 1983. Expression of bacterial genes in plant cells. Proceedings of the National Academy of Sciences of the United States of America 80: 4803-4807.

Furuta KM, Hellmann E, Helariutta Y. 2014. Molecular control of cell specification and cell differentiation during procambial development. Annual review of plant biology 65 : 607-638.

Haseloff J, Siemering KR, Prasher DC, Hodge S. 1997. Removal of a cryptic intron and subcellular localization of green fluorescent protein are required to mark transgenic Arabidopsis plants brightly. Proceedings of the National Academy of Sciences of the United States of America 94: 2122-2127.

Hazak O, Brandt B, Cattaneo P, Santiago J, Rodriguez-Villalon A, Hothorn M, Hardtke CS. 2017. Perception of root-active CLE peptides requires CORYNE function in the phloem vasculature. EMBO reports 18: 1367-1381. 
bioRxiv preprint doi: https://doi.org/10.1101/2019.12.21.885863; this version posted December 23, 2019. The copyright holder for this preprint (which was not certified by peer review) is the author/funder, who has granted bioRxiv a license to display the preprint in perpetuity. It is made available under aCC-BY-NC 4.0 International license.

Hellens RP, Edwards EA, Leyland NR, Bean S, Mullineaux PM. 2000. pGreen: a versatile and flexible binary Ti vector for Agrobacterium-mediated plant transformation. Plant molecular biology 42: 819-832.

Jiang L, Liu X, Xiong G, Liu H, Chen F, Wang L, Meng X, Liu G, Yu H, Yuan Y et al. 2013. DWARF 53 acts as a repressor of strigolactone signalling in rice. Nature 504: 401405.

Kondo Y, Nurani AM, Saito C, Ichihashi Y, Saito M, Yamazaki K, Mitsuda N, Ohme-Takagi M, Fukuda H. 2016. Vascular Cell Induction Culture System Using Arabidopsis Leaves (VISUAL) Reveals the Sequential Differentiation of Sieve Element-like Cells. Plant Cell 28: 1250-1262.

Krogan NT, Long JA. 2009. Why so repressed? Turning off transcription during plant growth and development. Curr Opin Plant Biol 12: 628-636.

Kurihara D, Mizuta Y, Sato Y, Higashiyama T. 2015. ClearSee: a rapid optical clearing reagent for whole-plant fluorescence imaging. Development (Cambridge, England) 142: 4168-4179.

Ladwig F, Dahlke RI, Stuhrwohldt N, Hartmann J, Harter K, Sauter M. 2015. Phytosulfokine Regulates Growth in Arabidopsis through a Response Module at the Plasma Membrane That Includes CYCLIC NUCLEOTIDE-GATED CHANNEL17, H+-ATPase, and BAK1. Plant Cell 27: 1718-1729.

Lampropoulos A, Sutikovic Z, WenzI C, Maegele I, Lohmann JU, Forner J. 2013. GreenGate--a novel, versatile, and efficient cloning system for plant transgenesis. PloS one 8: e83043.

Legrain P, Wojcik J, Gauthier JM. 2001. Protein--protein interaction maps: a lead towards cellular functions. Trends Genet 17: 346-352.

Liang Y, Ward S, Li P, Bennett T, Leyser O. 2016. SMAX1-LIKE7 Signals from the Nucleus to Regulate Shoot Development in Arabidopsis via Partially EAR Motif-Independent Mechanisms. Plant Cell 28: 1581-1601.

Lin TF, Saiga S, Abe M, Laux T. 2016. OBE3 and WUS Interaction in Shoot Meristem Stem Cell Regulation. PloS one 11: e0155657.

Lucas WJ, Groover A, Lichtenberger R, Furuta K, Yadav SR, Helariutta Y, He XQ, Fukuda H, Kang J, Brady SM et al. 2013. The plant vascular system: evolution, development and functions. Journal of integrative plant biology 55: 294-388.

Ma H, Duan J, Ke J, He Y, Gu X, Xu TH, Yu H, Wang Y, Brunzelle JS, Jiang Y et al. 2017. A D53 repression motif induces oligomerization of TOPLESS corepressors and promotes assembly of a corepressor-nucleosome complex. Science advances $\mathbf{3}$ : e1601217.

Marhava P, Aliaga Fandino AC, Koh SWH, Jelinkova A, Kolb M, Janacek DP, Breda AS, Cattaneo P, Hammes UZ, Petrasek J et al. 2019. Plasma membrane domain patterning and self-reinforcing polarity in Arabidopsis. Developmental cell.

Marhava P, Bassukas AEL, Zourelidou M, Kolb M, Moret B, Fastner A, Schulze WX, Cattaneo P, Hammes UZ, Schwechheimer C et al. 2018. A molecular rheostat adjusts auxin flux to promote root protophloem differentiation. Nature 558: 297-300.

Oparka KJ, Turgeon R. 1999. Sieve elements and companion cells-traffic control centers of the phloem. Plant Cell 11: 739-750.

Pauwels L, Barbero GF, Geerinck J, Tilleman S, Grunewald W, Perez AC, Chico JM, Bossche RV, Sewell J, Gil E et al. 2010. NINJA connects the co-repressor TOPLESS to jasmonate signalling. Nature 464: 788-791.

Rodriguez-Villalon A. 2016. Wiring a plant: genetic networks for phloem formation in Arabidopsis thaliana roots. New Phytol 210: 45-50.

Rodriguez-Villalon A, Gujas B, Kang YH, Breda AS, Cattaneo P, Depuydt S, Hardtke CS. 2014. Molecular genetic framework for protophloem formation. Proceedings of the National Academy of Sciences of the United States of America 111: 11551-11556.

Rodriguez-Villalon A, Gujas B, van Wijk R, Munnik T, Hardtke CS. 2015. Primary root protophloem differentiation requires balanced phosphatidylinositol-4,5-biphosphate levels and systemically affects root branching. Development (Cambridge, England) 142: $1437-1446$. 
Ross-Elliott TJ, Jensen KH, Haaning KS, Wager BM, Knoblauch J, Howell AH, Mullendore DL, Monteith AG, Paultre D, Yan D et al. 2017. Phloem unloading in Arabidopsis roots is convective and regulated by the phloem-pole pericycle. Elife 6: e24125.

Saiga S, Furumizu C, Yokoyama R, Kurata T, Sato S, Kato T, Tabata S, Suzuki M, Komeda Y. 2008. The Arabidopsis OBERON1 and OBERON2 genes encode plant homeodomain finger proteins and are required for apical meristem maintenance. Development (Cambridge, England) 135: 1751-1759.

Saiga S, Moller B, Watanabe-Taneda A, Abe M, Weijers D, Komeda Y. 2012. Control of embryonic meristem initiation in Arabidopsis by PHD-finger protein complexes. Development (Cambridge, England) 139: 1391-1398.

Sanchez R, Zhou MM. 2011. The PHD finger: a versatile epigenome reader. Trends Biochem Sci 36: 364-372.

Scacchi E, Salinas P, Gujas B, Santuari L, Krogan N, Ragni L, Berleth T, Hardtke CS. 2010. Spatio-temporal sequence of cross-regulatory events in root meristem growth. Proceedings of the National Academy of Sciences of the United States of America 107: 22734-22739.

Schindelin J, Arganda-Carreras I, Frise E, Kaynig V, Longair M, Pietzsch T, Preibisch S, Rueden C, Saalfeld S, Schmid B et al. 2012. Fiji: an open-source platform for biological-image analysis. Nat Methods 9: 676-682.

Scholthof HB. 2006. The Tombusvirus-encoded P19: from irrelevance to elegance. Nat Rev Microbiol 4: 405-411.

Schwab R, Ossowski S, Riester M, Warthmann N, Weigel D. 2006. Highly Specific Gene Silencing by Artificial MicroRNAs in Arabidopsis. Plant Cell 18: 1121-1133.

Soundappan I, Bennett T, Morffy N, Liang Y, Stanga JP, Abbas A, Leyser O, Nelson DC. 2015. SMAX1-LIKE/D53 family members enable distinct MAX2-dependent responses to strigolactones and karrikins in Arabidopsis. Plant Cell 27: 3143-3159.

Stanga JP, Morffy N, Nelson DC. 2016. Functional redundancy in the control of seedling growth by the karrikin signaling pathway. Planta 243: 1397-1406.

Stanga JP, Smith SM, Briggs WR, Nelson DC. 2013. SUPPRESSOR OF MORE AXILLARY GROWTH2 1 controls seed germination and seedling development in Arabidopsis. Plant physiology 163: 318-330.

Thomas CL, Schmidt D, Bayer EM, Dreos R, Maule AJ. 2009. Arabidopsis plant homeodomain finger proteins operate downstream of auxin accumulation in specifying the vasculature and primary root meristem. The Plant journal : for cell and molecular biology 59: 426-436.

Truernit E, Bauby H, Belcram K, Barthelemy J, Palauqui JC. 2012. OCTOPUS, a polarly localised membrane-associated protein, regulates phloem differentiation entry in Arabidopsis thaliana. Development (Cambridge, England) 139: 1306-1315.

Truernit E, Bauby H, Dubreucq B, Grandjean O, Runions J, Barthelemy J, Palauqui JC. 2008. High-resolution whole-mount imaging of three-dimensional tissue organization and gene expression enables the study of Phloem development and structure in Arabidopsis. Plant Cell 20: 1494-1503.

van den Berg C, Willemsen V, Hendriks G, Weisbeek P, Scheres B. 1997. Short-range control of cell differentiation in the Arabidopsis root meristem. Nature 390: 287-289.

Voinnet O, Rivas S, Mestre P, Baulcombe D. 2003. An enhanced transient expression system in plants based on suppression of gene silencing by the $\mathrm{p} 19$ protein of tomato bushy stunt virus. The Plant journal : for cell and molecular biology 33: 949-956.

Walker C, Bennett T. 2017. Reassessing the evolution of strigolactone synthesis and signalling. bioRxiv: 228320.

Wallner ES. 2018. Early events in phloem formation: Exploring the molecular network of SMXL3/4/5. in Faculty for Biosiences, p. 128. University of Heidelberg, Heidelberg.

Wallner ES, Lopez-Salmeron V, Belevich I, Poschet G, Jung I, Grunwald K, Sevilem I, Jokitalo E, Hell R, Helariutta Y et al. 2017. Strigolactone- and Karrikin-Independent SMXL Proteins Are Central Regulators of Phloem Formation. Current biology : CB 27: 1241-1247. 
Wallner ES, Lopez-Salmeron V, Greb T. 2016. Strigolactone versus gibberellin signaling: reemerging concepts? Planta 243: 1339-1350.

Wallner ES, Tonn N, Shi D, Jouannet V, Greb T. 2020. SUPPRESSOR OF MAX2 1-LIKE 5 promotes secondary phloem formation during radial stem growth. The Plant journal : for cell and molecular biology in press.

Wang L, Wang B, Jiang L, Liu X, Li X, Lu Z, Meng X, Wang Y, Smith SM, Li J. 2015. Strigolactone signaling in Arabidopsis regulates shoot development by targeting D53Like SMXL repressor proteins for ubiquitination and degradation. Plant Cell 27: 31283142.

Wu YY, Hou BH, Lee WC, Lu SH, Yang CJ, Vaucheret H, Chen HM. 2017. DCL2- and RDR6-dependent transitive silencing of SMXL4 and SMXL5 in Arabidopsis dcl4 mutants causes defective phloem transport and carbohydrate over-accumulation. The Plant journal : for cell and molecular biology 90: 1064-1078.

Zhou F, Lin Q, Zhu L, Ren Y, Zhou K, Shabek N, Wu F, Mao H, Dong W, Gan L et al. 2013. D14-SCF(D3)-dependent degradation of D53 regulates strigolactone signalling. Nature 504: 406-410. 
bioRxiv preprint doi: https://doi.org/10.1101/2019.12.21.885863; this version posted December 23, 2019. The copyright holder for this

preprint (which was not certified by peer review) is the author/funder, who has granted bioRxiv a license to display the preprint in perpetuity. It is made available under aCC-BY-NC 4.0 International license.

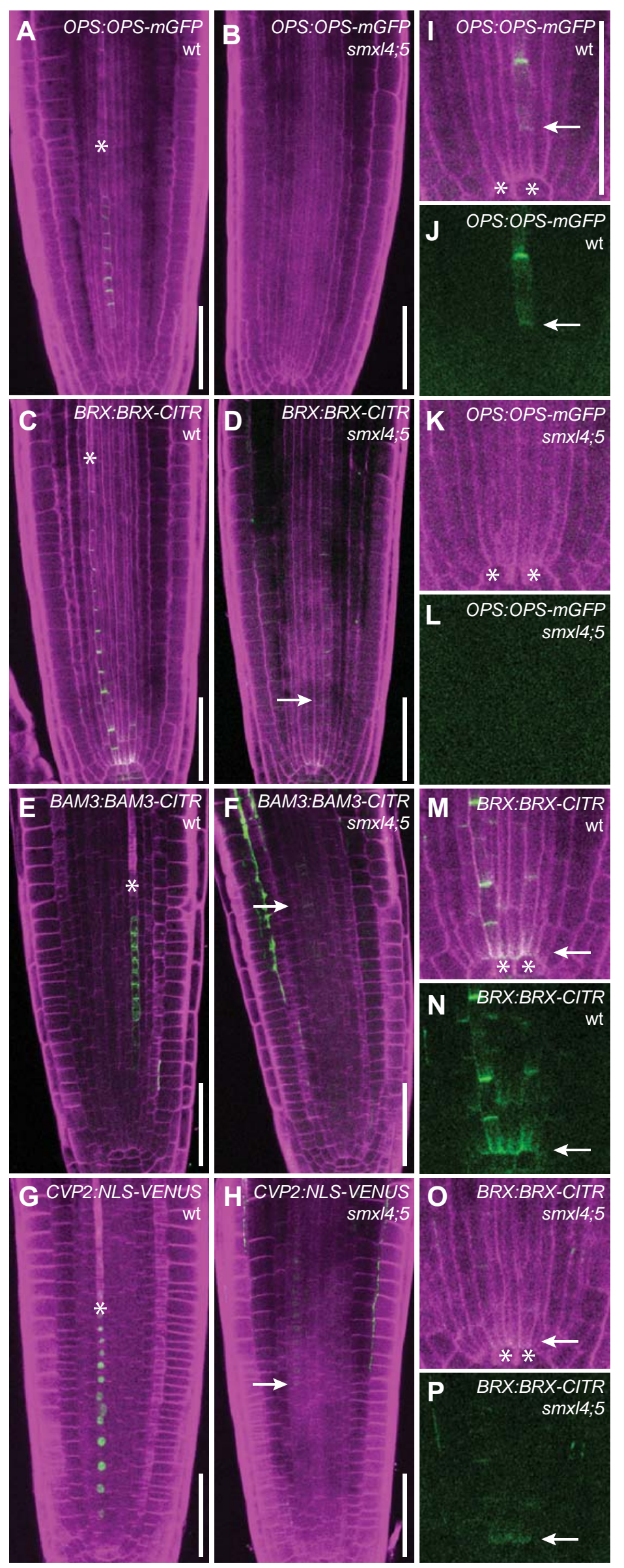

Figure 1: Phloem-related genes are less active in smxl4;smxl5 mutants $(\mathrm{A}-\mathrm{H})$ Comparison of OPS:OPS-GFP (A, B), BRX:BRX-CITRINE (C, D), BAM3:BAM3-CITRINE, and CVP2:NLS-VENUS $(\mathrm{G}, \mathrm{H})$ reporter activities in wild type $(A, C, E, G)$ and smxl4;smx/5 double mutants (B, D, F, H). Asterisks depict the first differentiating $\mathrm{SE}$. Arrows point to earliest detectable reporter activities. Scale bars represent $50 \mu \mathrm{m}$.

(I - P) OPS:OPS-GFP (I-L) and BRX:BRX-CITRINE (M-P) close to the QC in wild type (I, J, M, N) and smx/4;smx/5 mutants $(K, L, O, P)$. In J, L, N, and $P$, fluorescent signals are depicted without counterstaining. Asterisks indicate QC cells. Arrows point to earliest detectable reporter activities. Scale bar in (I) represents $50 \mu \mathrm{m}$. Same magnification in I-P. 

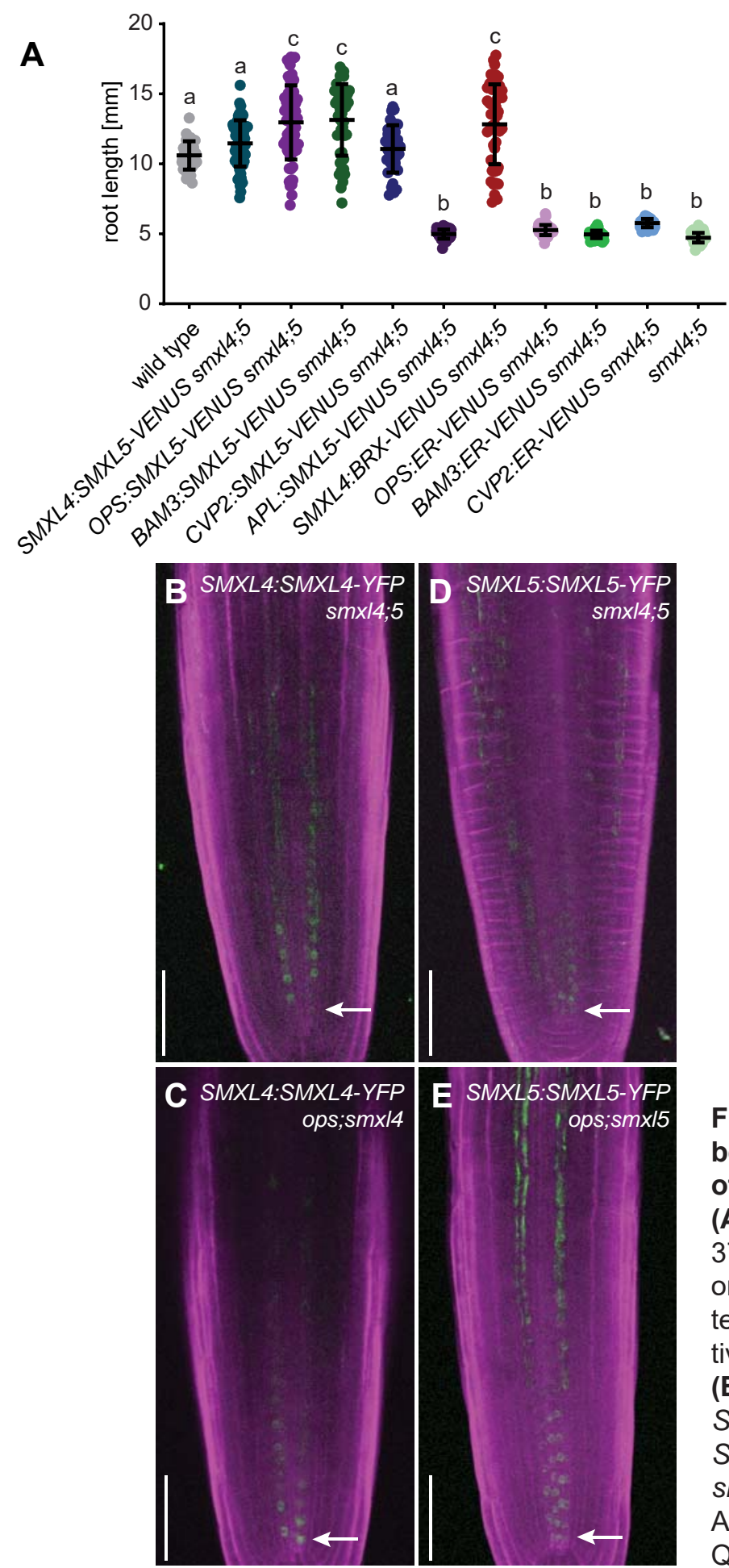

Figure 2 : Analysis of interaction between SMXL4 and SMXL5 with other phloem regulators

(A) Root length of five day-old plants. $n=$ 37-75. Statistical groups determined by one-way ANOVA and post-hoc Tukey's test $(95 \% \mathrm{Cl})$. Shown is one representative experiment of three repetitions.

(B - E) Comparison of SMXL4:SMXL4-YFP and SMXL5:SMXL5-YFP reporter activities in smxl4;smx/5 and smxl;ops mutants.

Arrows indicate the signals closest to the QC. Scale bars represent $50 \mu \mathrm{m}$. 


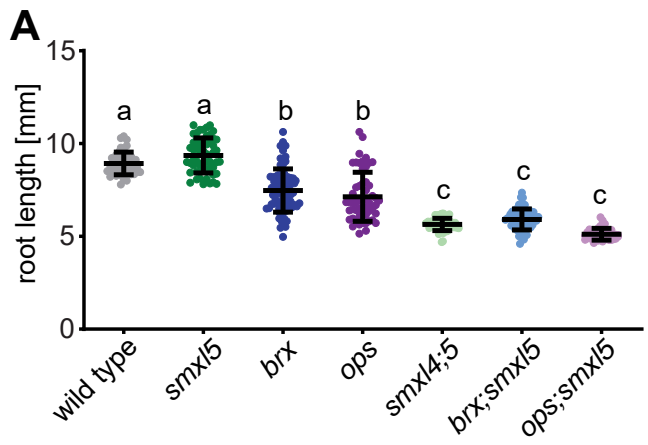

B

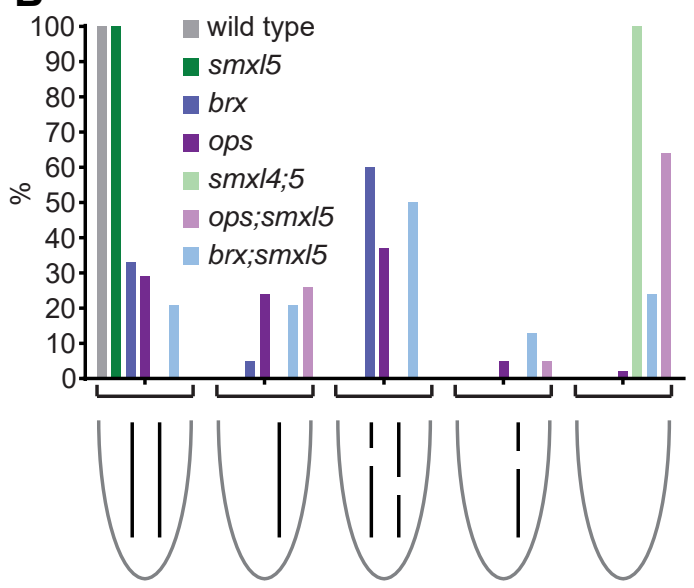

Figure 3: Genetic interaction of SMXL5 with OPS and BRX

(A) Root length of five day-old wild type (WT), smx/5, brx, ops, smx/4;smx/5, brx;smx 15 , and ops;smx/5 plants. $\mathrm{n}=$ 38-76 for ech group. Statistical groups determined by one-way ANOVA and post-hoc Tukey's HSD test $(95 \% \mathrm{Cl})$. Shown is one representative experiment of three repetitions.

(B) Phenotypic characterization of phloem development of two day-old wild type, smxl5, brx, ops, smx/4;smxl5, brx;smxI5, and ops;smxI5 plants. $\mathrm{n}=$ 97-129 for each group. 

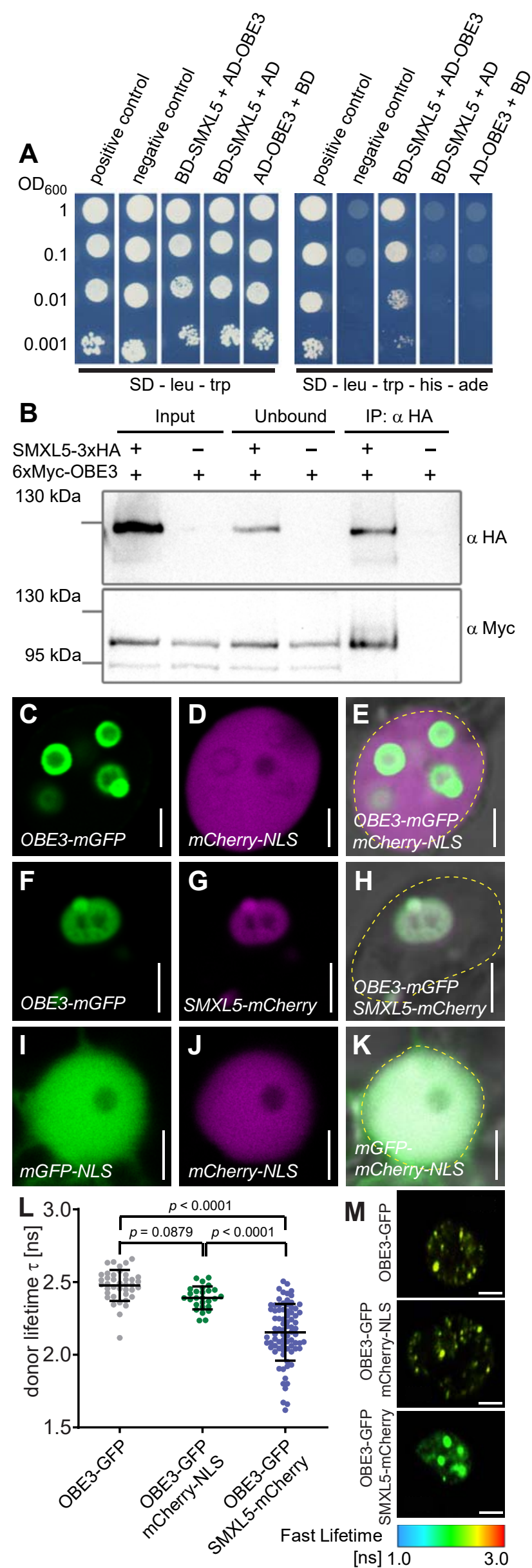

Figure 4: SMXL5 and OBE3 proteins interact

(A) The SMXL5 protein was expressed in yeast fused to the GAL4 DNA binding domain (BD) and OBE3 fused to the GAL4 activation domain (AD). All strains contained $A D$ - and $B D$-expressing plasmids either alone or fused with SMXL5, OBE3 or control proteins, respectively. Growth on SD-leu-trp indicate the presence of both plasmids, growth on SD-leu-trp-his-ade medium indicate the presence of plasmids and protein interaction.

(B) Interaction of SMXL5-3xHA and 6xMyc-OBE3 proteins by co-immunoprecipitation (co-IP) and subsequent Western blot analysis after transient overexpression in N. benthamiana. 'Input' represents unprocessed protein extracts, 'unbound' show proteins that remained in the extract after IP and 'IP: $\alpha$ HA' depicts samples after immunoprecipitation by a-HA-beads. Western blots were probed by $\alpha \mathrm{HA}$ or $\alpha \mathrm{Myc}$ antibodies, respectively. Signals revealed an expected SMXL5-3xHA protein size of approximately $120 \mathrm{kDa}$. The size of the detected 6xMyc-OBE3 protein $(\sim 100 \mathrm{kDa})$ exceeded the expected size of $92 \mathrm{kDa}$.

(C - K) Fluorescent signals and bright field images of epidermal $N$. benthamiana nuclei transiently co-expressing OBE3-mGFP/mCherry (C-E), OBE3-mGFP/SMXL5-mCherry (F-H) and mGFP-NLS/mCherry-NLS (I-K). The dashed yellow line indicates the outlines of nuclei in merged images $(\mathrm{E}, \mathrm{H}, \mathrm{K})$. Scale bars represent $5 \mu \mathrm{m}$. (L) FRET-FLIM analysis of transiently transformed $N$. benthamiana epidermal leaf cells expressing the OBE3-mGFP donor in the presence of SMXL5-mCherry or NLS-mCherry or without an mCherry acceptor. Error bars indicate standard deviation. P-values for lifetime comparisons are based on Dunn post hoc analysis following a Wilcoxon / Kruskal-Wallis test. Data were derived from three biological replicates with $n=$ 27-80. To test for homogeneity of variance, a Brown-Forsythe test was applied. As the variances are not homogenous a Wilcoxon / Kruskal-Wallis test was carried out followed by a Dunn post hoc analysis.

(M) Heat maps of representative nuclei used for FLIM measurements. The donor lifetimes of OBE3-mGFP are color-coded according to the scale at the bottom. Size bars represent $4 \mu \mathrm{m}$. 

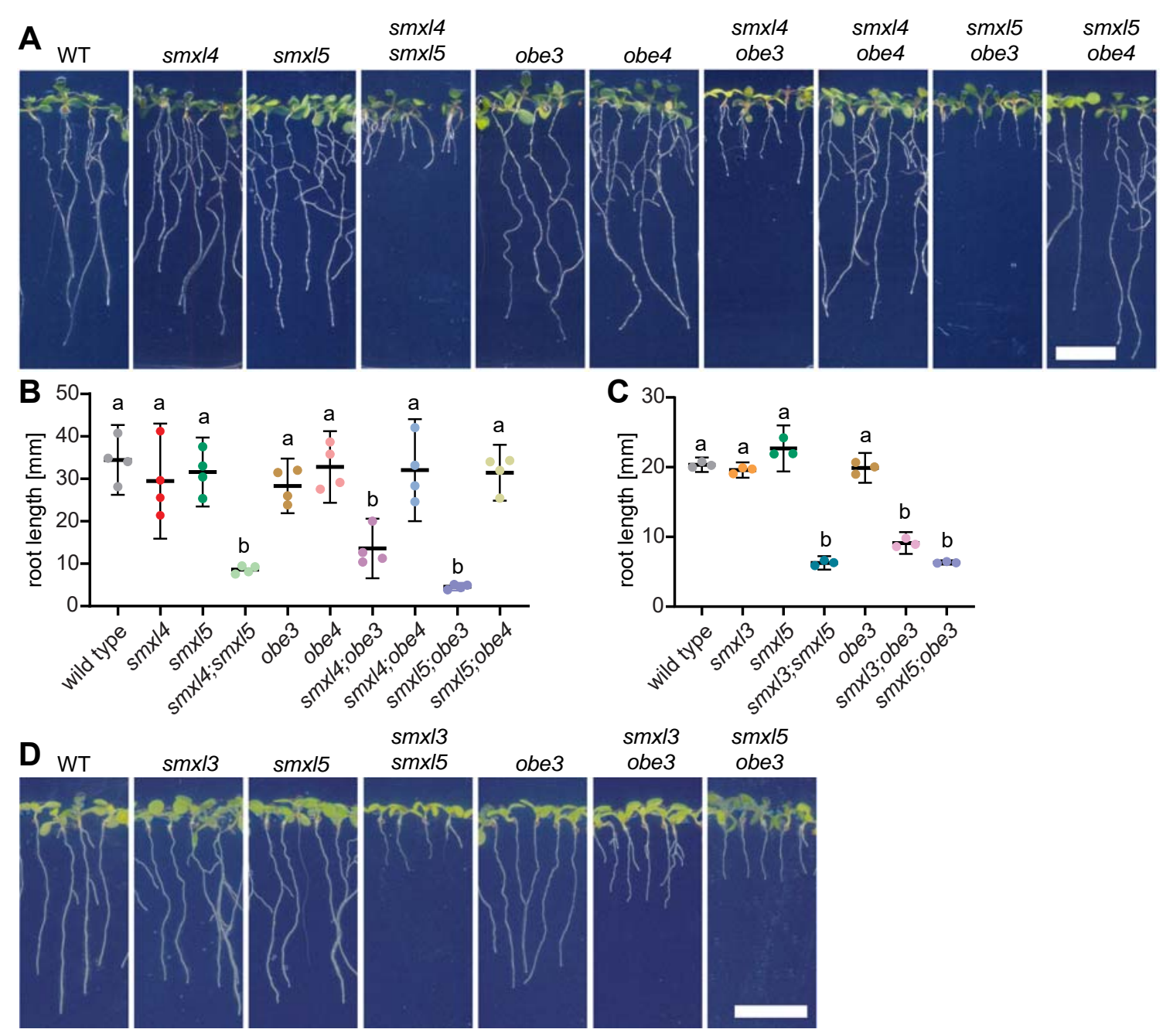

Figure 5: OBE3 genetically interacts with $S M X L 3 / 4 / 5$ in root growth regulation

(A) 10 day-old wild type, smx/4, smx/5, smxl4;smx/5, obe3, obe4, smxl4;obe3, smxl4;obe4, smxl5;obe3, smx/5;obe4 seedlings are shown from left to right. Scale bar represents $1 \mathrm{~cm}$.

(B) Quantification of root length depicted in A. Mean values of four independent experiments $(n=15-55$ per experiment and genotype) were analyzed by a one-way ANOVA with post-hoc Tukey HSD $(95 \% \mathrm{Cl})$. Statistical groups are marked by letters.

(C) Quantification of root length depicted in D. Mean values of three independent experiments $(n=62-74$ per experiment and genotype) were analyzed by a one-way ANOVA with post-hoc Tamhane-T2 (95\% Cl). Statistical groups are marked by letters.

(D) 10 day-old wild type, smx/3, smx/5, smx/3;smx/5, obe3, smx/3;obe3, smxl5;obe3 seedlings are shown from left to right. Scale bar represents $1 \mathrm{~cm}$. 

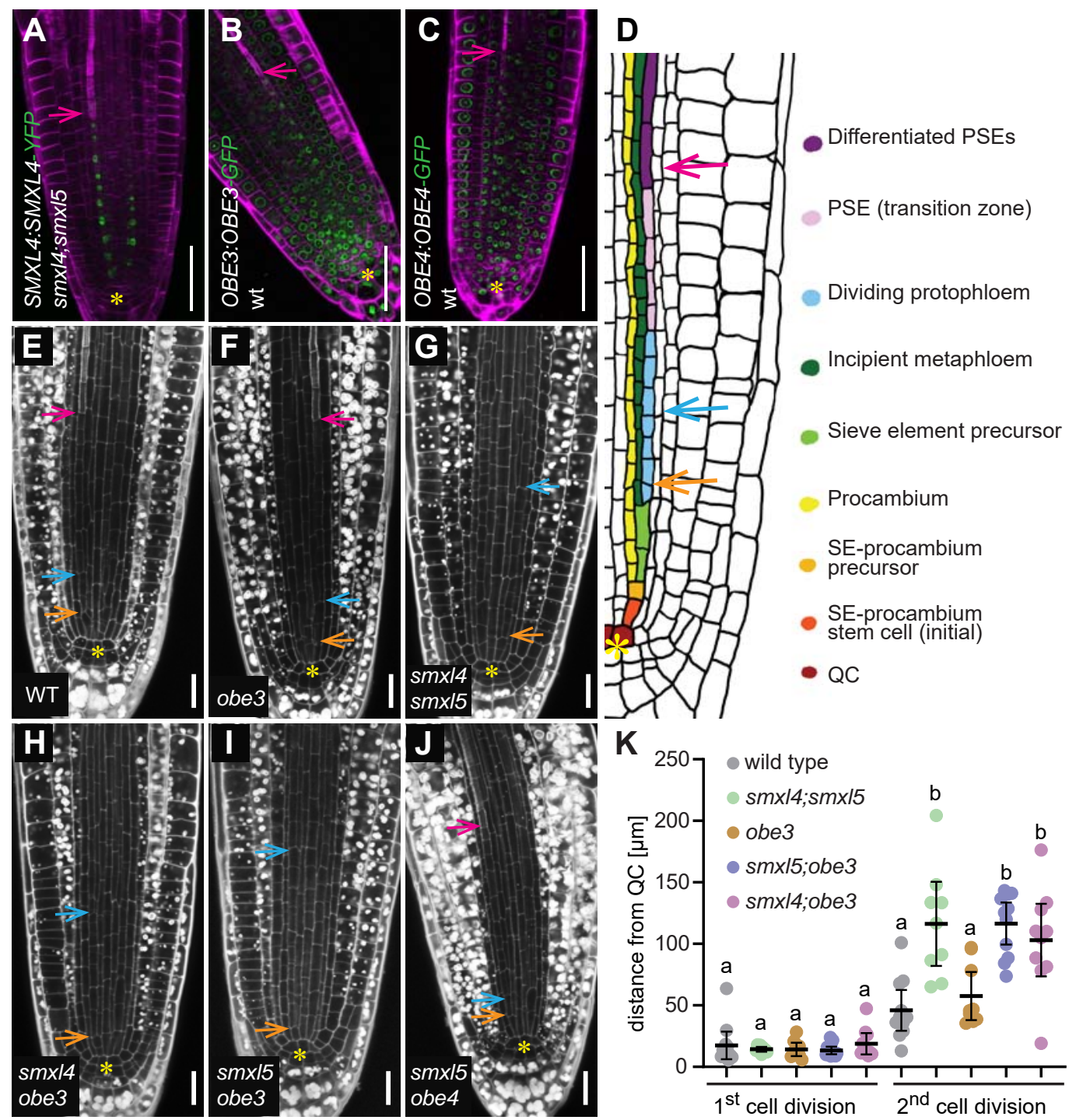

Figure 6: OBE3 interacts with SMXL5 during protophloem formation

(A - C) Phloem-specific activity of SMXL4:SMXL4-YFP (A) coincides with activty of OBE3:OBE3-GFP (B) and OBE4:OBE4-GFP $(\mathrm{C})$ reporters in the developing phloem. Fluorescent signals (green) and cell wall staining by Direct Red 23 (magenta) were detected by confocal microscopy. Pink arrows point to the first differentiated SE indicated by enhanced cell wall staining. Scale bars represent $50 \mu \mathrm{m}$.

(D) Schematic representation of one developing phloem pole at the root tip. Two tangential cell divisions generate SE precursor and procambium (orange arrow) and proto- and metaphloem cell lineages (blue arrow), respectively. Differentiated SEs are marked by a pink arrow. The QC is marked by a yellow asterisk. (E - J) Phloem formation in 2 day-old wild type (E), obe3 (F), smx/4;smxl5 (G), smxl4;obe3 (H), smxl5;obe3 (I) and smxl5;obe4 (J) root tips. Cell walls were stained by mPS-PI (white). Yellow asterisks mark the QC. Enhanced mPS-PI staining indicates differentiation of SEs (pink arrows) in wild type (E), obe3 (F) and obe4;smx/5 (G). Orange and blue arrows mark the first and second tangential division, respectively, in the developing phloem cell lineage. Scale bars represent $20 \mu \mathrm{m}$.

(K) The distance from the QC to the first and second tangential division shown in D-I was quantified $(\mathrm{n}=$ 9-11). Statistical groups are indicated by letters and were determined by a one-way ANOVA with post-hoc Tukey HSD $(95 \% \mathrm{Cl})$. Distances of 1 st cell divisions and 2nd cell divisions were compared independently. 

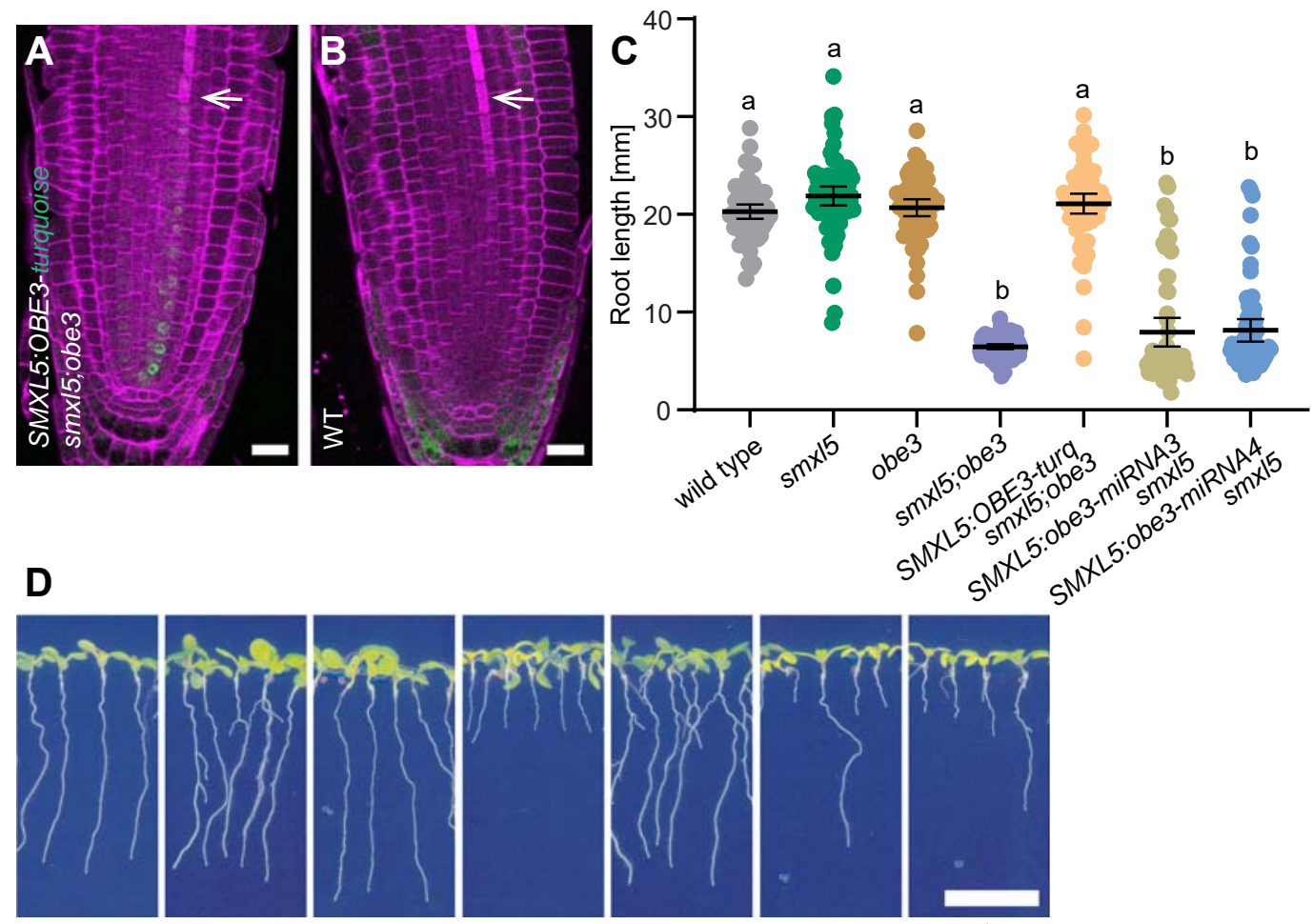

WT

smx15

obe3

smxl5;obe3

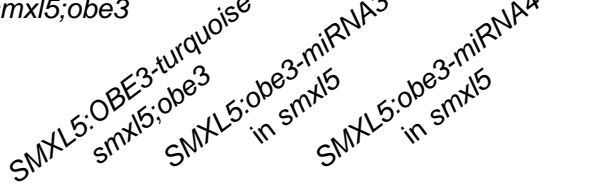

Figure 7: Phloem-specific OBE3 expression is sufficient for promoting root growth

(A - B) Seven day-old smx/5;obe3 root tips carrying an SMXL5:OBE3-turquoise reporter (green signal, B) were compared to a non-transformed wild type (WT) root tip (B). Cell walls were stained by DirectRed (magenta). White arrows mark differentiated SEs. Scale bars indicate $20 \mu \mathrm{m}$.

(C) Root length quantification of plants depicted in D. Results from one representative experiment out of three independent experiments $(n=61-71$ per experiment and genotype) are shown. Mean values were analyzed by one-way ANOVA with post-hoc Tamhane-T2 $(95 \% \mathrm{Cl})$. Statistical groups are indicated by letters.

(D) 10 day-old wild type, smxl5, obe3, smxl5;obe3, SMXL5:OBE3-turquoise/smxl5;obe3, SMXL5:obe3-miRNA3/smxI5 and SMXL5:obe3-miRNA4/smxI5 seedlings are shown from left to right. Scale bar represents $1 \mathrm{~cm}$. 

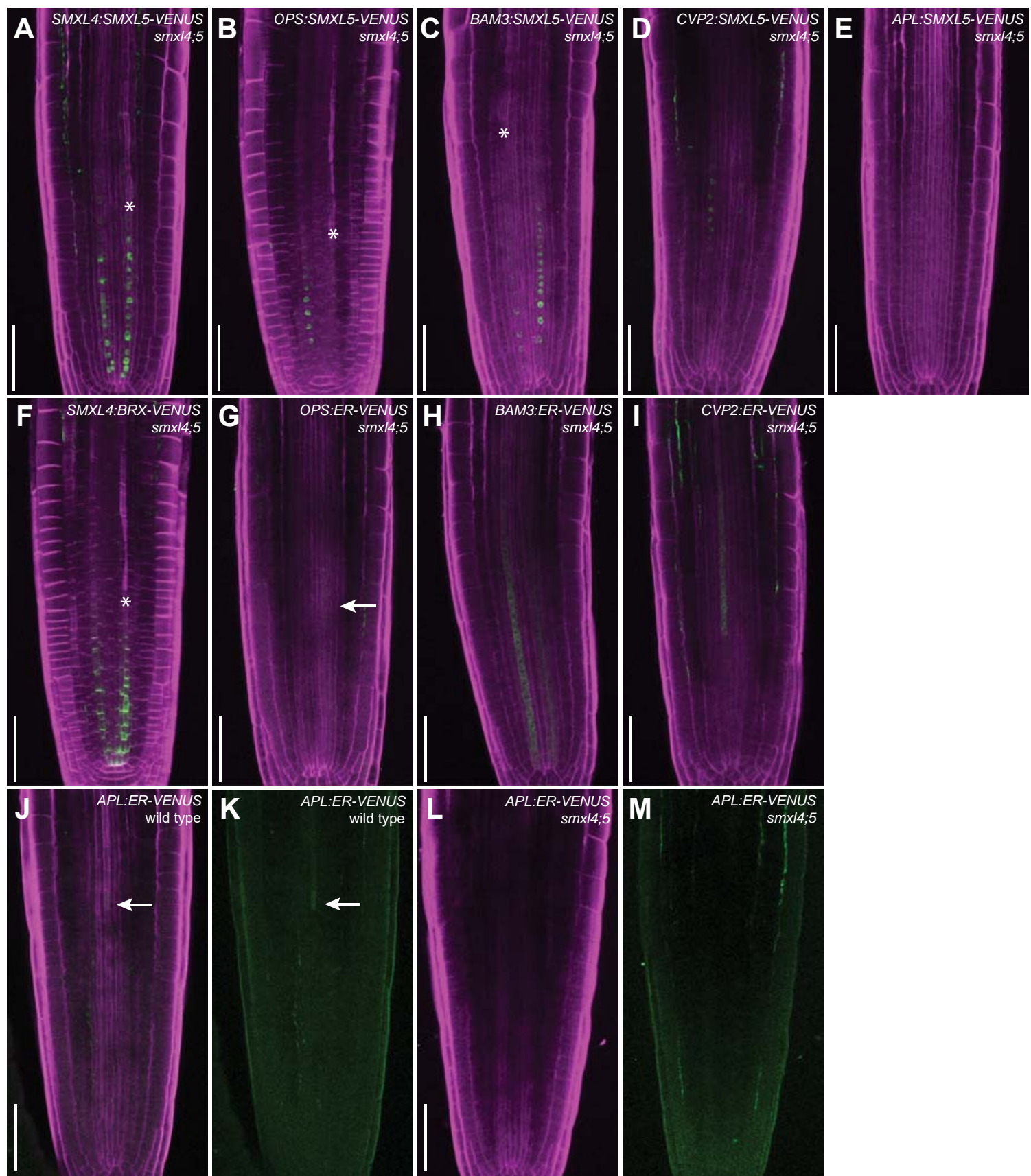

Supplementary Figure 1: Expression of SMXL5-VENUS protein fusions in smxl4;smxI5 mutants in comparison to promoter reporters.

(A - E) Expression of SMXL5-VENUS protein fusions under the control of different heterologous promoters. Differentiated SEs are indicated by the asterisks.

(F) Detection of the BRX-VENUS protein fusion expressed under the control of the SMXL4 promoter. Differentiated SEs are indicated by the asterisk.

(G - I) Detection of OPS:ER-VENUS, BAM3:ER-VENUS, and CVP2:ER-VENUS reporter activities in smxl4;smx/5 mutants. Arrow in $\mathrm{G}$ points to a weakly detectable reporter-derived signal.

( $\mathrm{J}-\mathbf{M})$ Detection of $A P L$ :ER-VENUS reporter activity in wild type $(\mathrm{J}, \mathrm{K})$ and $s m x / 4 ; s m \times 15$ mutants $(\mathrm{L}, \mathrm{M}) . \mathrm{K}$ and $M$ show the same root tip as in $J$ and $L$, respectively, without the counter stain signal. Scale bars in all pictures represent $50 \mu \mathrm{m}$. Arrows in $\mathrm{J}$ and $\mathrm{K}$ point to a weakly detectable reporter-derived signal. 
bioRxiv preprint doi: https://doi.org/10.1101/2019.12.21.885863; this version posted December 23, 2019. The copyright holder for this preprint (which was not certified by peer review) is the author/funder, who has granted bioRxiv a license to display the preprint in perpetuity. It is made available under aCC-BY-NC 4.0 International license.
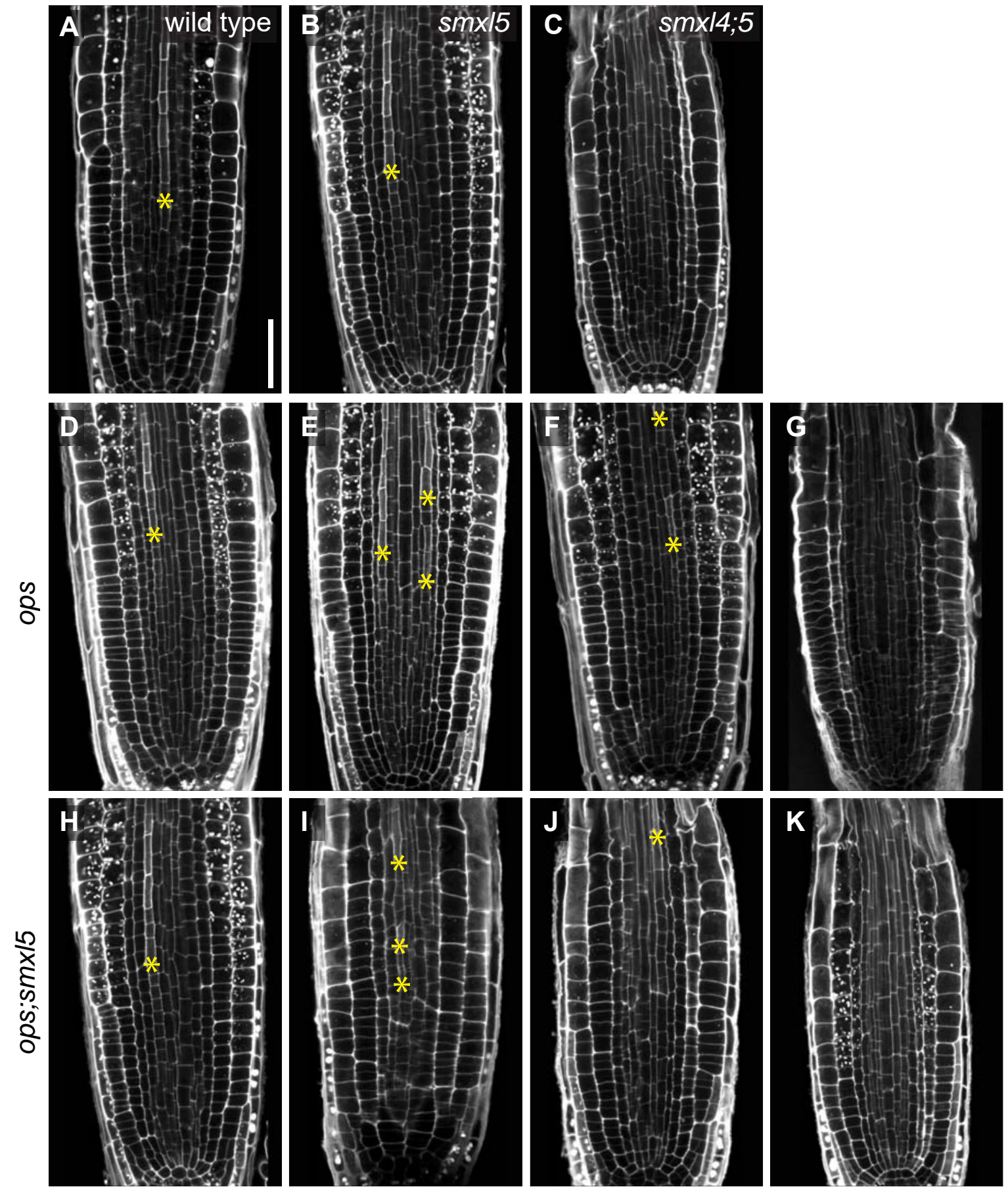

Supplementary Figure 2: Characterization of phloem development in smxl and ops mutants.

(A - K) Phloem development is monitored in wild type (A), smxl5 (B), smxl4;smxl5 (C), ops (D-G) and ops;smxl5 (H-K) mutant backgrounds by confocal analysis of mPS-PI-stained root tips. Asterisks indicate the most apical appearance of differentiated SEs. In case 'gaps' are observed, more than one asterisk is depicted. 
bioRxiv preprint doi: https://doi.org/10.1101/2019.12.21.885863; this version posted December 23, 2019. The copyright holder for this

preprint (which was not certified by peer review) is the author/funder, who has granted bioRxiv a license to display the preprint in perpetuity. It is made available under aCC-BY-NC 4.0 International license.
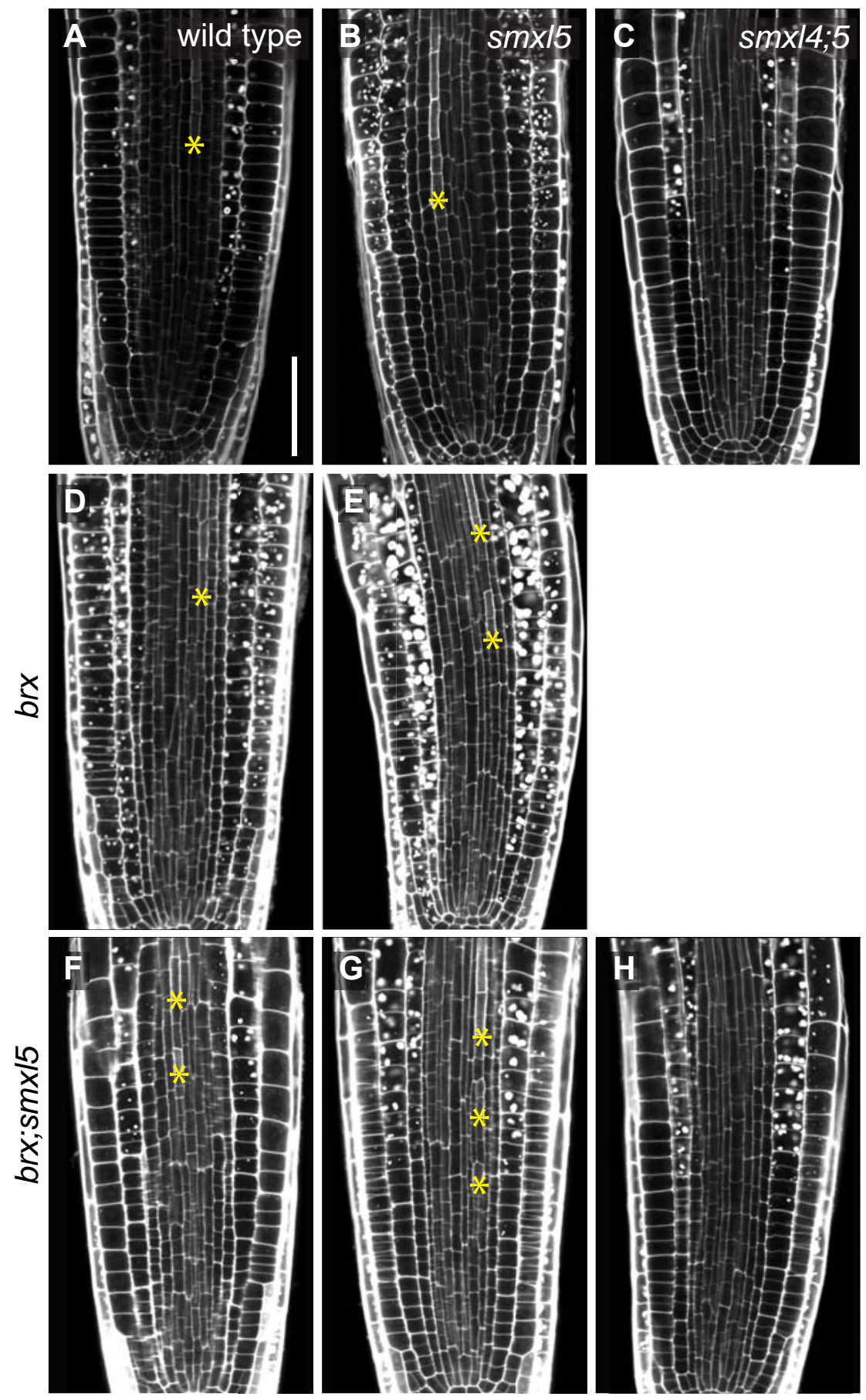

Supplementary Figure 3: Characterization of phloem development in smxl and brx mutants.

(A - H) Phloem development is monitored in wild type (A), smxl5 (B), smxl4;smxl5 (C), brx (D-E) and brx;smxl5 (F-H) mutant backgrounds by confocal analysis of mPS-PI-stained root tips. Asterisks indicate the most apical appearance of differentiated SEs. In case 'gaps' are observed, more than one asterisk is depicted. 
A
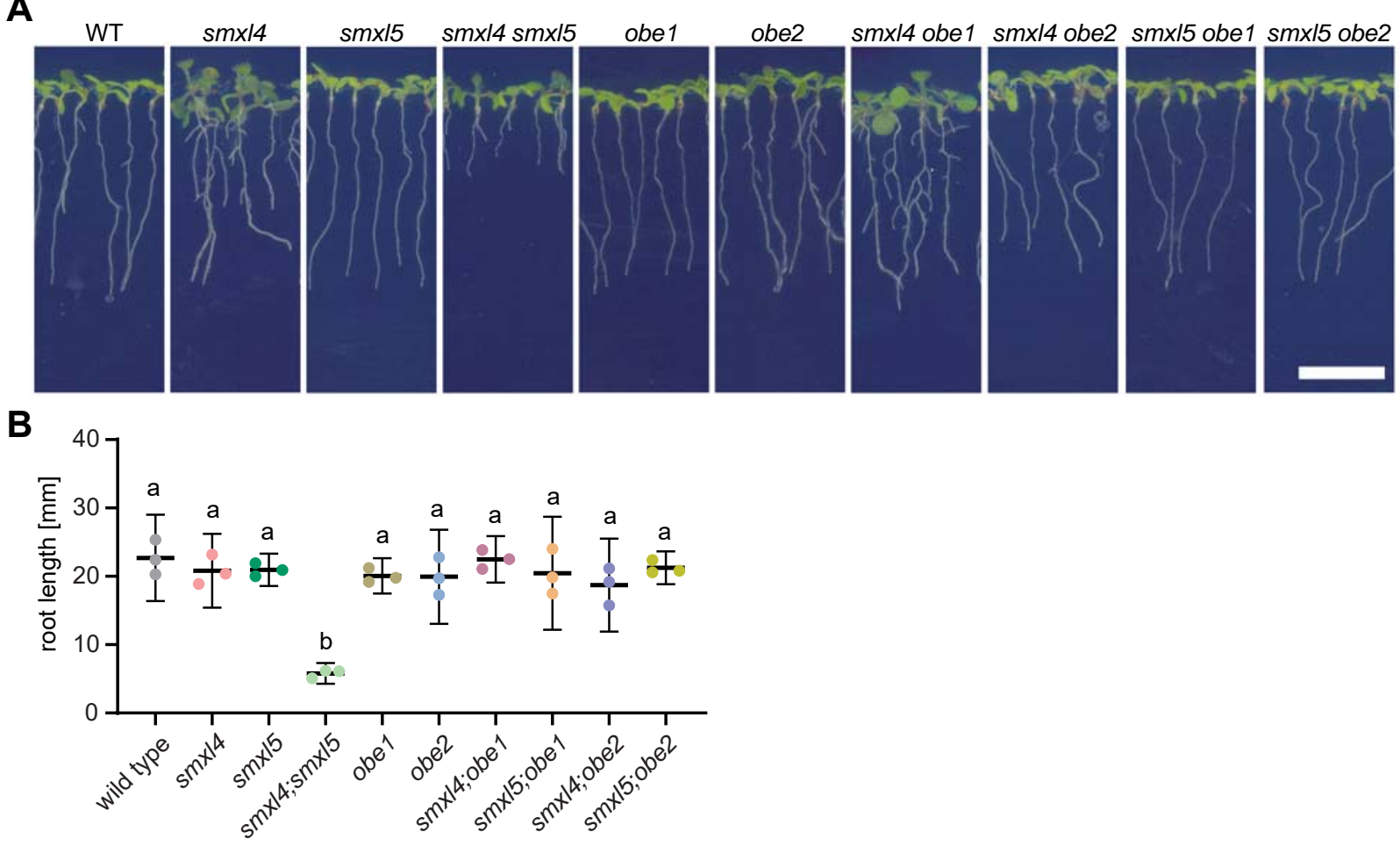

Supplementary Figure 4: SMXL4 or SMXL5 genes do not genetically interact with OBE1 or OBE2 genes (A) 10 day-old wild type, smx/4, smxl5, smxl4;smx/5, obe1, obe2, smxl4;obe1, smxl4;obe2, smxl5;obe1, smxI5;obe2 seedlings are shown from left to right. Scale bar represents $1 \mathrm{~cm}$.

(B) Quantification of root lengths depicted in A. Mean values of three independent experiments $(n=34-75$ per experiment and genotype) were analyzed by a one-way ANOVA with post-hoc Tukey HSD $(95 \% \mathrm{Cl})$. Statistical groups are indicated by letters. 
bioRxiv preprint doi: https://doi.org/10.1101/2019.12.21.885863; this version posted December 23, 2019. The copyright holder for this preprint (which was not certified by peer review) is the author/funder, who has granted bioRxiv a license to display the preprint in perpetuity. It is made available under aCC-BY-NC 4.0 International license.
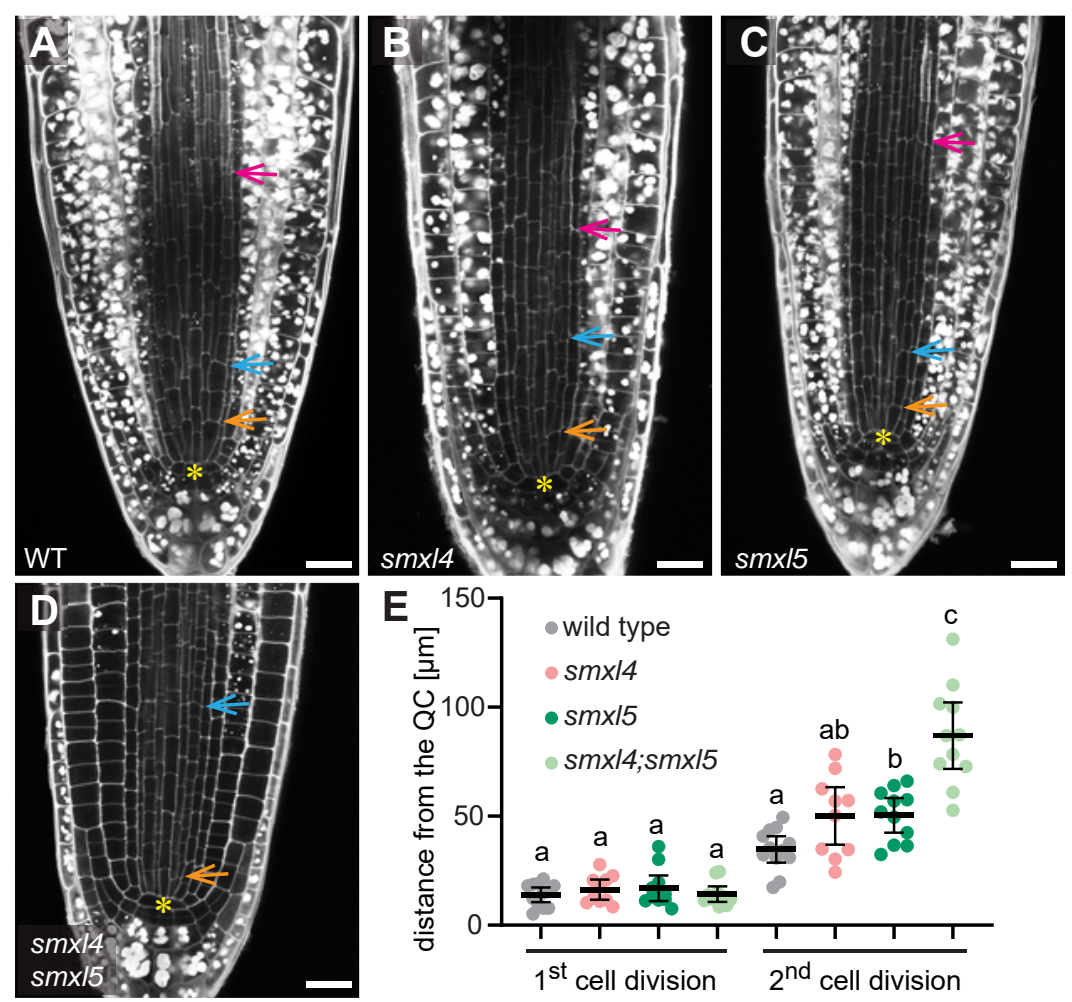

\section{Supplementary Figure 5: SEs form in smxI4 and smxl5 single mutants}

(A - D) 2 day-old mPS-PI-stained root tips of wild type (A), smxl4 (B), smx/5 (C) and smx/4;smx/5 (D) plants. Differentiating SEs were observed in wild type, $s m x / 4$ and $s m x l 5$ (pink arrows). Tangential cell divisions are marked by orange and blue arrows. The QC is indicated by a yellow asterisk. Scale bars represent $20 \mu \mathrm{m}$.

(E) The distance of the first and second tangential division from the QC for plants shown in A-D was quantified $(n=10-12)$. Statistical groups marked by letters were determined by one-way ANOVA with post-hoc Tamhane-T2 $(95 \% \mathrm{Cl})$. Distances of 1 st cell divisions and 2 nd cell divisions were compared independently. 


\section{Supplementary Table 1: Oligonucleotides used in this study}

\begin{tabular}{|c|c|c|c|}
\hline & Used for & Primer name & Primer sequence $\left(5^{\prime} \rightarrow 3^{\prime}\right)$ \\
\hline \multirow{21}{*}{$\begin{array}{l}\text { D } \\
\overline{0} \\
\overline{2} \\
0 \\
\frac{0}{0} \\
0\end{array}$} & $s m \times / 3-1$ & SALK_024706_LP & CCCTACACAGCTCTTCACGAG \\
\hline & & SALK_024706_RP & TGCCTCTCTCACAAGAAAAGC \\
\hline & $s m \times 14-1$ & SALK_037136-LP & TTGAAGCCATGGAAGAATCTG \\
\hline & & SALK_037136-RP & ACAAAGAACAATGCGGTCAAG \\
\hline & $s m \times 15-1$ & SALK_018522-LP & TGTCTCATTGAAGCCAAAACC \\
\hline & & SALK_018522-RP & AATGGTGCAAGAATTCTGACG \\
\hline & obe1-1 & SALK_075710_LP & ATTCGACTCAAACGTTGAACG \\
\hline & & SALK_075710_RP & CTCGTCTGGACAAACTTCTGC \\
\hline & obe2-1 & obe2-1_RP & CTTCAAGATCAAGGTATTGACCTAAATTACC \\
\hline & & obe2-1_LP & CATTTGGTGAGGATGATTCGAACC \\
\hline & & obe2-1_Insertion & GATCAGATTGTCGTTTCCCGCC \\
\hline & obe3-1 & SALK_042597_LP & TTCCAACAACAAAGGCTTTTTG \\
\hline & & SALK_042597_RP & TTTCCCACAAAACGAAACAAG \\
\hline & obe4-1 & SALK_082338_LP & TGCTTATTGACACCTGACTGC \\
\hline & & SALK_082338_RP & AAGAAAAGCGAGGAGGAAGTG \\
\hline & & ops_RP & TCTTCCTCTAAAAAGCCTCCG \\
\hline & & ops_LP & CACACCGTTGGTTTGGTTAAC \\
\hline & SALK_insert & SALK_LBa1 & TGGTTCACGTAGTGGGCCATCG \\
\hline & $b r x-2$ & $b r x-2 \_R P$ & GTCAGTGTTTGCTTCCTCTCTATG \\
\hline & & $b r x-2 \angle P$ & TATTTCCTTGTCTAGGTAAGAATCC \\
\hline & & brx-2_Insertion & TGATCCATGTAGATTTCCCGGACATGAA \\
\hline \multirow{14}{*}{ 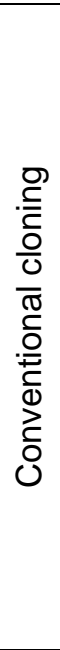 } & \multirow{2}{*}{ pEW31 } & 3xHA_for & ACTAGGATCCTCCGCTTCCTCCTGCGTAGTCCGGGACATCATAC \\
\hline & & 3xHA_rev & ACTAAAGCTTATGTATCCTTATGATGTACCTGATTATG \\
\hline & \multirow{2}{*}{ pEW33 } & 3XHA_SMXL5_for & $\begin{array}{l}\text { ACTAGGATCCAGGAGGAAGTGGAGGAAGTTATCCTTATGATGTAC } \\
\text { CTG }\end{array}$ \\
\hline & & 3xHA_SMXL5_rev & ACTACCCGGGTCATGCGTAGTCCGGGACATC \\
\hline & \multirow{2}{*}{$\begin{array}{l}\text { miRNA } \\
\text { PCRs for } \\
p E W 45 / 46\end{array}$} & P-0950 Oligo A & AACAGGTCTCAAACACTGCAGCCCCAAACACACGC \\
\hline & & P-0951 Oligo B & AACAGGTCTCTGCAGCCCCATGGCGATGCC \\
\hline & \multirow{4}{*}{ pEW45 } & I_miRNAsOBE3_3 & GATAATTTCTGGTATTGACTCAGTCTCTCTTTTGTATTCC \\
\hline & & II_miRNAaOBE3_3 & GACTGAGTCAATACCAGAAATTATCAAAGAGAATCAATGA \\
\hline & & III_miRNA*sOBE3_3 & GACTAAGTCAATACCTGAAATTTTCACAGGTCGTGATATG \\
\hline & & IV_miRNA*aOBE3_3 & GAAAATTTCAGGTATTGACTTAGTCTACATATATATTCCT \\
\hline & \multirow{4}{*}{ pEW46 } & I_miRNAsOBE3_4 & GATAATTTCTGGTATTGACTCATTCTCTCTTTTGTATTCC \\
\hline & & II_miRNAaOBE3_4 & GAATGAGTCAATACCAGAAATTATCAAAGAGAATCAATGA \\
\hline & & III_miRNA*SOBE3_4 & GAATAAGTCAATACCTGAAATTTTCACAGGTCGTGATATG \\
\hline & & IV_miRNA*aOBE3_4 & $\begin{array}{l}\text { GAAAATTTCAGGTATTGACTTATTCTACATATATATTCCT } \\
\end{array}$ \\
\hline \multirow{18}{*}{ 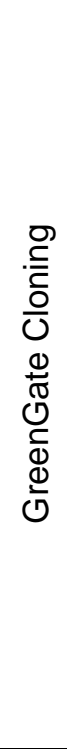 } & \multirow{2}{*}{ pNT51 } & pOPS-for & AACAGGTCTCAACCTCAATGATGAATTATACTTACGTGGG \\
\hline & & pOPS-rev & AACAGGTCTCATGTTGACGGGAAATGGTGGTTAATC \\
\hline & \multirow{2}{*}{ pVL84 } & SMXL5_GG1 & AACAGGTCTCAGGCTCAATGCGAACAGGTGGTTATACG \\
\hline & & SMXL5_GG2 & AACAGGTCTCACTGACTCCTCGAACTTGGAAACTTG \\
\hline & \multirow{2}{*}{ pNT48 } & pBAM3-for & AACAGGTCTCAACCTGGTGGTTGGAGATG \\
\hline & & pBAM3-rev & AACAGGTCTCATGTTTGTAACATCAGAAAAATAAAAAC \\
\hline & \multirow{2}{*}{ pNT9 } & pCVP2_FOR & AACA GGTCTC A ACCT CACAACTACCTAACTGATG \\
\hline & & pCVP2_REV & AACA GGTCTC A TGTT TGTTGCTTCTTCTCTGCAAG \\
\hline & \multirow{2}{*}{ pNT42 } & pSMXL4-for & AACAGGTCTCAACCTACCATGTCGAACCCTCCAATTG \\
\hline & & pSMXL4-rev & AACAGGTCTCATGTTCACAAAACCACCCACCTTAAATC \\
\hline & \multirow{2}{*}{ pNT71 } & BRX CDS for & AACAGGTCTCAGGCTCAATGTTTTCTTGCATAGCTTG \\
\hline & & BRX CDS rev & AACAGGTCTCACTGAGAGGTACTGTGTTTGTATTCTC \\
\hline & \multirow{2}{*}{ pVL85 } & OBE3_GG1 & AACAGGTCTCAGGCTCAATGATCGGAGAGAAAGATC \\
\hline & & OBE3_GG3 & AACAGGTCTCACTGATCCTACCAATTGTTGTCTTG \\
\hline & \multirow{2}{*}{ pEW75 } & cMyc_ModulB_for & AACAGGTCTCAAACAATGGAGCAAAAGCTC \\
\hline & & cMyc_ModulB_rev & AACAGGTCTCAAGCCCAAGTCCTCTTCAGA \\
\hline & \multirow{2}{*}{ pCW192 } & A02603 & AGTGAAGCTTGGTCTCAAACAATGGTGAGCAAGGGCGA \\
\hline & & A03062 & GTTAGGTCTCAAGCCGGACTTGTACAGCTCGTCCATG \\
\hline
\end{tabular}


Supplementary Table 2: Destination modules created by GreenGate cloning (this study)

\begin{tabular}{|c|c|c|c|c|c|c|c|}
\hline \multicolumn{8}{|c|}{ List of destination modules (GreenGate Cloning) } \\
\hline \multirow{2}{*}{ Final construct (name) } & \multicolumn{7}{|c|}{ Entry modules (list) } \\
\hline & A & $\mathrm{B}$ & $\mathrm{C}$ & $\mathrm{D}$ & $E$ & $\mathrm{~F}$ & Z \\
\hline $\begin{array}{l}\text { OPS:SMXL5-VENUS } \\
\text { (pNT52) }\end{array}$ & pNT51 & $p V L 50$ & pVL84 & $\begin{array}{c}\text { pGGD- } \\
\text { mVENUS/ } \\
\text { pD00587 }\end{array}$ & $p V L 66$ & pVL53 & $p V L 11$ \\
\hline $\begin{array}{l}\text { BAM3:SMXL5-VENUS } \\
\text { (pNT49) }\end{array}$ & pNT48 & $p V L 50$ & $p V L 84$ & $\begin{array}{c}\text { pGGD- } \\
\text { mVENUS/ } \\
\text { pD00587 }\end{array}$ & $p V L 66$ & pVL53 & $p V L 11$ \\
\hline $\begin{array}{l}\text { CVP2:SMXL5-VENUS } \\
\text { (pNT16) }\end{array}$ & pNT9 & $p V L 50$ & $p V L 84$ & $\begin{array}{c}\text { pGGD- } \\
\text { mVENUS/ } \\
\text { pD00587 }\end{array}$ & $p V L 66$ & pVL53 & $p V L 11$ \\
\hline $\begin{array}{l}\text { APL:SMXL5-VENUS } \\
(p N T 10)\end{array}$ & pVL35 & $p V L 50$ & pVL84 & $\begin{array}{c}\text { pGGD- } \\
\text { mVENUS/ } \\
\text { pD00587 }\end{array}$ & pVL25 & pVL53 & pVL11 \\
\hline $\begin{array}{l}\text { OPS:ER-VENUS } \\
\text { (pNT53) }\end{array}$ & pNT51 & pVL63 & $p V L 70$ & $p V L 71$ & $p V L 66$ & pVL53 & $p V L 11$ \\
\hline $\begin{array}{l}\text { BAM3:ER-VENUS } \\
(p N T 50)\end{array}$ & pNT48 & pVL63 & $p V L 70$ & $p V L 71$ & $p V L 66$ & $p V L 53$ & pVL11 \\
\hline $\begin{array}{l}\text { CVP2:ER-VENUS } \\
\text { (pNT69) }\end{array}$ & pNT9 & pVL63 & $p V L 70$ & $p V L 71$ & pVL66 & pVL53 & pVL11 \\
\hline $\begin{array}{l}\text { APL:ER-VENUS } \\
\text { (pNT68) }\end{array}$ & pVL35 & $p V L 63$ & $p V L 70$ & $p V L 71$ & $p V L 66$ & pVL53 & $p V L 11$ \\
\hline $\begin{array}{l}\text { SMXL4:BRX-VENUS } \\
\text { (pNT72) }\end{array}$ & pNT42 & $p V L 50$ & pNT71 & $\begin{array}{c}\text { pGGD- } \\
\text { mVENUS/ } \\
\text { pD00587 }\end{array}$ & $p V L 66$ & $p V L 53$ & $p V L 11$ \\
\hline $\begin{array}{l}\text { SMXL5:OBE3- } \\
\text { mTurquoise } \\
\text { (pEW72) }\end{array}$ & $p V L 28$ & $p V L 50$ & $p V L 85$ & pVL101 & pVL20 & pVL53 & pVL11 \\
\hline $\begin{array}{l}\text { 35S:5Xc-Myc-OBE3 } \\
\text { (pEW78) }\end{array}$ & pDS34 & pEW75 & pVL85 & pVL51 & $p V L 66$ & pVL53 & $p V L 11$ \\
\hline $\begin{array}{l}\text { 35S:SMXL5-mCherry } \\
\text { (pVL122) }\end{array}$ & pDS34 & $p V L 50$ & pVL84 & pVL119 & $p V L 66$ & pVL53 & pVL11 \\
\hline $\begin{array}{l}\text { 35S:OBE3-mGFP } \\
\text { (pVL127) }\end{array}$ & pDS34 & pVL50 & $p V L 85$ & $p V L 69$ & pVL66 & pVL53 & $p V L 11$ \\
\hline $\begin{array}{l}\text { 35S:mCherry-NLS } \\
\text { (pMG103) }\end{array}$ & $\begin{array}{l}p G G A 00 \\
4 / p D S 34\end{array}$ & $\begin{array}{c}p G G B 0 \\
03 / p L V 5 \\
0\end{array}$ & $\begin{array}{c}\text { pGGCO } \\
15\end{array}$ & pGGD007 & $\begin{array}{c}p G G E 0 \\
01 / p V L 6 \\
6\end{array}$ & $\begin{array}{c}\text { pGGFOO } \\
7\end{array}$ & $\begin{array}{l}\text { pGGZOO } \\
3 / p V L 11\end{array}$ \\
\hline $\begin{array}{l}\text { UBI10:mGFP- } \\
\text { mCherry-NLS } \\
\text { (pCW194) }\end{array}$ & $\begin{array}{c}\text { pGGAOO } \\
6\end{array}$ & $\begin{array}{c}p C W 19 \\
2\end{array}$ & $\begin{array}{c}p C W 19 \\
3\end{array}$ & pGGD007 & $\begin{array}{l}\text { pGGEO } \\
09\end{array}$ & $\begin{array}{c}\text { pGGFOO } \\
7\end{array}$ & $\begin{array}{l}\text { pGGZOO } \\
3 / p V L 11\end{array}$ \\
\hline
\end{tabular}

Supplementary Table 3: Entry modules received for GreenGate cloning

\begin{tabular}{|l|l|l|}
\hline \multicolumn{2}{|c|}{ List of received entry modules (for GreenGate Cloning) } \\
\hline Name (see list) & Construct & Reference \\
\hline$p V L 50$ & B-Dummy (pGGB003) & Lampropoulos et al. 2013 \\
\hline$p G G D-m V E N U S$ & pD00587 & VENUS in Module D, Karin Schumacher \\
\hline$p V L 66$ & Rbcs term (pGGE001) & Lampropoulos et al. 2013 \\
\hline
\end{tabular}


bioRxiv preprint doi: https://doi.org/10.1101/2019.12.21.885863; this version posted December 23, 2019. The copyright holder for this preprint (which was not certified by peer review) is the author/funder, who has granted bioRxiv a license to display the preprint in perpetuity. It is made available under aCC-BY-NC 4.0 International license.

\begin{tabular}{|l|l|l|}
\hline$p V L 53$ & SulfR (pGGF012) & Lampropoulos et al. 2013 \\
\hline$p V L 11$ & pGGZ003 & Lampropoulos et al. 2013 \\
\hline$p V L 63$ & Signal Peptide (ER) & Lampropoulos et al. 2013 \\
\hline$p V L 70$ & YFP/VENUS (pGGC023) & Schuerholz, Lopez-Salmeron et al. 2018 \\
\hline$p V L 71$ & HDEL & Lampropoulos et al. 2013 \\
\hline$p V L 35$ & APL & Schuerholz, Lopez-Salmeron et al. 2018 \\
\hline$p V L 25$ & APL terminator & Schuerholz, Lopez-Salmeron et al. 2018 \\
\hline$p V L 28$ & SSMXL5 & Schuerholz, Lopez-Salmeron et al. 2018 \\
\hline$p V L 101$ & pSW394 & mTurquoise in Mod D, Sebastian Wolf \\
\hline$p V L 20$ & SMXL5 terminator & Schuerholz, Lopez-Salmeron et al. 2018 \\
\hline$p D S 34$ & pGGA004 & Lampropoulos et al. 2013 \\
\hline$p V L 51$ & D-Dummy (pGGD002) & Lampropoulos et al. 2013 \\
\hline$p G G C 015$ & mCherry & Lampropoulos et al. 2013 \\
\hline$p G G D 007$ & linker-NLS & Lampropoulos et al. 2013 \\
\hline$p G G F 007$ & KanR & Lampropoulos et al. 2013 \\
\hline$p G G A 006$ & DUBC10 & Lampropoulos et al. 2013 \\
\hline$p G G E 009$ & UBC10 terminator & Lampropoulos et al. 2013 \\
\hline$p V L 119$ & mCherry (pGGD003) & Lampropoulos et al. 2013 \\
\hline$p V L 69$ & mGFP (pGGD001) & Lampropoulos et al. 2013 \\
\hline & & \\
\hline
\end{tabular}




\section{Resource Table}

\begin{tabular}{|c|c|c|}
\hline RESOURCE & SOURCE & IDENTIFIER \\
\hline \multicolumn{3}{|l|}{ Antibodies } \\
\hline $\begin{array}{l}\text { Anti-HA-Peroxidase High Affinity (3F10), rat } \\
\text { monoclonal }\end{array}$ & $\begin{array}{l}\text { Roche; Basel, } \\
\text { Switzerland }\end{array}$ & Cat\# 11867423001 \\
\hline $\begin{array}{l}\text { c-Myc Antibody sc-40 HRP (9E10), mouse } \\
\text { monoclonal }\end{array}$ & \begin{tabular}{|l} 
Santa Cruz \\
Biotechnology, \\
Santa Cruz, USA
\end{tabular} & Cat\# sc-40 \\
\hline \multicolumn{3}{|l|}{ Bacterial and Virus Strains } \\
\hline $\begin{array}{l}\text { Agrobacterium tumefaciens C58C1: RifR with } \\
\text { pSoup plasmid (TetR) }\end{array}$ & $\begin{array}{l}\text { Ashby et al., } 1988 \\
\text { Hellens et al., } 2000\end{array}$ & \\
\hline $\begin{array}{l}\text { Agrobacterium tumefaciens ASE: KanR, CamR } \\
\text { with pSoup+ plasmid (TetR) }\end{array}$ & $\begin{array}{l}\text { Merrit et al., } 1999 \\
\text { Hellens et al., } 2000\end{array}$ & \\
\hline $\begin{array}{l}\text { Agrobacterium tumefaciens C58C1: RifR with } \\
\text { 35S:P19 }\end{array}$ & Voinnet et al. 2013 & \\
\hline \multicolumn{3}{|l|}{ Chemicals, Peptides, and Recombinant Proteins } \\
\hline DirectRed 23 & $\begin{array}{l}\text { Sigma-Aldrich; St. } \\
\text { Louis, USA }\end{array}$ & Cat\#212490 \\
\hline ClearSee & Kurihara et al. 2015 & \\
\hline Propidium iodide & $\begin{array}{l}\text { Sigma-Aldrich; St. } \\
\text { Louis, USA }\end{array}$ & Cat\#81845 \\
\hline $\begin{array}{l}\text { Nicotiana infiltration induction buffer ( } 10 \mathrm{mM} \text { MES } \\
\mathrm{pH} 5.5,10 \mathrm{mM} \text { MgSO4, } 150 \mu \mathrm{M} \text { Acetosyringone) }\end{array}$ & This paper & $\mathrm{N} / \mathrm{A}$ \\
\hline cOmplete $^{\mathrm{TM}}$ Protease Inhibitor Cocktail & $\begin{array}{l}\text { Sigma-Aldrich; St. } \\
\text { Louis, USA }\end{array}$ & Cat\#11697498001 \\
\hline $\begin{array}{l}\text { Protein extraction buffer (50 nM Na}{ }_{3} \mathrm{PO}_{4}, 150 \mathrm{mM} \\
\mathrm{NaCl}, 10 \% \text { Glycerol, } 5 \mathrm{mM} \text { EDTA, } 10 \mu \mathrm{M} \beta- \\
\text { mercaptoethanol, } 0.1 \% \text { Triton X-100, } 2 \mathrm{mM} \\
\mathrm{NaVO}_{4}, 2 \mathrm{mM} \mathrm{NaF} \text {, cOmplete tablet (1/2 tablet per } \\
20 \mathrm{ml}), 20 \mu \mathrm{M} \mathrm{MG} 132,1 \mathrm{mM} \text { PMSF) }\end{array}$ & This paper & $\mathrm{N} / \mathrm{A}$ \\
\hline $\begin{array}{l}\text { Wash buffer I ( } 50 \mathrm{nM} \mathrm{Na} \mathrm{PO}_{4}, 150 \mathrm{mM} \mathrm{NaCl}, 10 \% \\
\text { Glycerol, } 5 \mathrm{mM} \text { EDTA, } 0.1 \% \text { triton X-100, } 2 \mathrm{mM} \\
\mathrm{NaVO}_{4}, 2 \mathrm{mM} \mathrm{NaF} \text {, cOmplete tablet (1/2 tablet per } \\
20 \mathrm{ml}), 20 \mu \mathrm{M} \mathrm{MG} 132,1 \mathrm{mM} \text { PMSF) }\end{array}$ & This paper & $\mathrm{N} / \mathrm{A}$ \\
\hline $\begin{array}{l}\text { Wash buffer II ( } 50 \mathrm{nM} \mathrm{Na}_{3} \mathrm{PO}_{4}, 150 \mathrm{mM} \mathrm{NaCl}, 10 \% \\
\text { Glycerol, } 5 \mathrm{mM} \text { EDTA) }\end{array}$ & This paper & $\mathrm{N} / \mathrm{A}$ \\
\hline Sample Buffer, Laemmli 2x Concentrate & $\begin{array}{l}\text { Sigma-Aldrich; St. } \\
\text { Louis, USA }\end{array}$ & Cat\#S3401 \\
\hline $\begin{array}{l}\text { SuperSignal }{ }^{\mathrm{TM}} \text { West Femto Maximum Sensitivity } \\
\text { Substrate }\end{array}$ & $\begin{array}{l}\text { Thermo-Scientific; } \\
\text { Waltham, USA }\end{array}$ & Cat\#34094 \\
\hline $\begin{array}{l}\text { PageRuler }{ }^{\mathrm{TM}} \text { Plus Prestained Protein Ladder, } 10 \text { to } \\
250 \mathrm{kDa}\end{array}$ & $\begin{array}{l}\text { Thermo-Scientific; } \\
\text { Waltham, USA }\end{array}$ & Cat\#26619 \\
\hline Bio-Rad Protein Assay Dye Reagent Concentrate & $\begin{array}{l}\text { Bio-Rad } \\
\text { Laboratories; } \\
\text { Hercules, USA }\end{array}$ & Cat\#5000006EDU \\
\hline
\end{tabular}




\begin{tabular}{|c|c|c|}
\hline \multicolumn{3}{|l|}{ Experimental Models: Organisms/Strains } \\
\hline Arabidopsis: wild type Col-0 & Gudrun Böhmdorfer & \\
\hline Arabidopsis: smxl5-1 (SALK_018522) & Wallner et al. 2017 & $\mathrm{~N} / \mathrm{A}$ \\
\hline Arabidopsis: smxl4-1 (SALK_037136) & Wallner et al. 2017 & $\mathrm{~N} / \mathrm{A}$ \\
\hline Arabidopsis: smxl3-1 (SALK_024706) & Wallner et al. 2017 & $\mathrm{~N} / \mathrm{A}$ \\
\hline Arabidopsis: obe1-1 (SALK_075710) & Saiga et al. 2008 & $\mathrm{~N} / \mathrm{A}$ \\
\hline Arabidopsis: obe2-1 (KG16805) & Saiga et al. 2008 & $\mathrm{~N} / \mathrm{A}$ \\
\hline Arabidopsis: obe3-2/tta1-2 (SALK_042597) & Saiga et al. 2012 & $\mathrm{~N} / \mathrm{A}$ \\
\hline Arabidopsis: obe4-1/tta2-1 (SALK_082338) & Saiga et al. 2012 & $\mathrm{~N} / \mathrm{A}$ \\
\hline $\begin{array}{l}\text { Arabidopsis: smxl4-1 smxl5-1 (SALK_037136, } \\
\text { SALK_018522) }\end{array}$ & Wallner et al. 2017 & $\mathrm{~N} / \mathrm{A}$ \\
\hline $\begin{array}{l}\text { Arabidopsis: smxl4-1 obe1-1 (SALK_037136, } \\
\text { SALK_075710) }\end{array}$ & This paper & $\mathrm{N} / \mathrm{A}$ \\
\hline $\begin{array}{l}\text { Arabidopsis: smxl5-1 obe1-1 (SALK_018522, } \\
\text { SALK_075710) }\end{array}$ & This paper & $\mathrm{N} / \mathrm{A}$ \\
\hline $\begin{array}{l}\text { Arabidopsis: smxl4-1 obe2-1 (SALK_037136, } \\
\text { KG16805) }\end{array}$ & This paper & $\mathrm{N} / \mathrm{A}$ \\
\hline $\begin{array}{l}\text { Arabidopsis: smxl5-1 obe2-1 (SALK_018522, } \\
\text { KG16805) }\end{array}$ & This paper & $\mathrm{N} / \mathrm{A}$ \\
\hline $\begin{array}{l}\text { Arabidopsis: smxl4-1 obe3-2 (SALK_037136, } \\
\text { SALK 042597) }\end{array}$ & This paper & $\mathrm{N} / \mathrm{A}$ \\
\hline $\begin{array}{l}\text { Arabidopsis: smxl5-1 obe3-2 (SALK_018522, } \\
\text { SALK_042597) }\end{array}$ & This paper & $\mathrm{N} / \mathrm{A}$ \\
\hline $\begin{array}{l}\text { Arabidopsis: smxl3-1 obe3-2 (SALK_024706, } \\
\text { SALK_042597) }\end{array}$ & This paper & $\mathrm{N} / \mathrm{A}$ \\
\hline $\begin{array}{l}\text { Arabidopsis: smxl4-1 obe4-1 (SALK_037136, } \\
\text { SALK_082338) }\end{array}$ & This paper & $\mathrm{N} / \mathrm{A}$ \\
\hline $\begin{array}{l}\text { Arabidopsis: smxl5-1 obe4-1(SALK_018522, } \\
\text { SALK_082338) }\end{array}$ & This paper & $\mathrm{N} / \mathrm{A}$ \\
\hline Arabidopsis: brx-2 (pSKI15) & $\begin{array}{l}\text { Rodrigues et al. } \\
2009\end{array}$ & $\mathrm{~N} / \mathrm{A}$ \\
\hline Arabidopsis: ops-2 (SALK_139316) & Truernit et al. 2012 & $\mathrm{~N} / \mathrm{A}$ \\
\hline $\begin{array}{l}\text { Arabidopsis: brx-2 smxl5-1 (pSKI15, } \\
\text { SALK_018522) }\end{array}$ & This paper & $\mathrm{N} / \mathrm{A}$ \\
\hline $\begin{array}{l}\text { Arabidopsis: ops-2 smxl5-1 (SALK_139316, } \\
\text { SALK_018522) }\end{array}$ & This paper & $\mathrm{N} / \mathrm{A}$ \\
\hline Arabidopsis: SMXL4:SMXL4-YFP in wild type & Wallner et al. 2017 & $\mathrm{~N} / \mathrm{A}$ \\
\hline $\begin{array}{l}\text { Arabidopsis: OBE3:OBE3-GFP/TTA1:TTA1-GFP in } \\
\text { wild type }\end{array}$ & Saiga et al. 2012 & $\mathrm{~N} / \mathrm{A}$ \\
\hline $\begin{array}{l}\text { Arabidopsis: OBE4:OBE4-GFP/TTA2:TTA2-GFP in } \\
\text { wild type }\end{array}$ & Saiga et al. 2012 & $\mathrm{~N} / \mathrm{A}$ \\
\hline $\begin{array}{l}\text { Arabidopsis: SMXL5:OBE3-turquoise in smxI5-1 } \\
\text { obe3-2 (SALK_018522, SALK_042597) }\end{array}$ & This paper & $\mathrm{N} / \mathrm{A}$ \\
\hline $\begin{array}{l}\text { Arabidopsis: SMXL5:obe3-miRNA3 in smx/5-1 } \\
\text { (SALK_018522) }\end{array}$ & This paper & $\mathrm{N} / \mathrm{A}$ \\
\hline $\begin{array}{l}\text { Arabidopsis: SMXL5:obe3-miRNA4 in smxl5-1 } \\
\text { (SALK_018522) }\end{array}$ & This paper & $\mathrm{N} / \mathrm{A}$ \\
\hline $\begin{array}{l}\text { Arabidopsis: OPS:SMXL5-VENUS (pNT52) in } \\
\text { smxl4-1 smxI5-1 (SALK_037136, SALK_018522) }\end{array}$ & This paper & $\mathrm{N} / \mathrm{A}$ \\
\hline OPS:ER-VENUS (pNT53) in wild type & This paper & $\mathrm{N} / \mathrm{A}$ \\
\hline
\end{tabular}




\begin{tabular}{|c|c|c|}
\hline $\begin{array}{l}\text { BAM3:SMXL5-VENUS (pNT49) in smx/4-1 smx/5-1 } \\
\text { (SALK_037136, SALK_018522) }\end{array}$ & This paper & $\mathrm{N} / \mathrm{A}$ \\
\hline BAM3:ER-VENUS (pNT50) in wild type & This paper & N/A \\
\hline $\begin{array}{l}\text { CVP2:SMXL5-VENUS (pNT16) in smx/4-1 smx/5-1 } \\
\text { (SALK_037136, SALK_018522) }\end{array}$ & This paper & $\mathrm{N} / \mathrm{A}$ \\
\hline CVP2:ER-VENUS (pNT69) in wild type & This paper & N/A \\
\hline $\begin{array}{l}\text { APL:SMXL5-VENUS (pNT10) in smx/4-1 smx/5-1 } \\
\text { (SALK_037136, SALK_018522) }\end{array}$ & This paper & N/A \\
\hline APL:ER-VENUS (pNT68) in wild type & This paper & $\mathrm{N} / \mathrm{A}$ \\
\hline $\begin{array}{l}\text { SMXL4:BRX-VENUS (pNT72) in smx/4-1 smx/5-1 } \\
\text { (SALK_037136, SALK_018522) }\end{array}$ & This paper & $\mathrm{N} / \mathrm{A}$ \\
\hline OPS:OPS-GFP in wild type & $\begin{array}{l}\text { Rodriguez-Villalon et } \\
\text { al. } 2014\end{array}$ & N/A \\
\hline $\begin{array}{l}\text { OPS:OPS-mGFP6 in smxl4-1 smxl5-1 } \\
\text { (SALK_037136, SALK_018522) }\end{array}$ & This paper & $\mathrm{N} / \mathrm{A}$ \\
\hline$B R X: B R X-C I T R I N E$ in wild type & $\begin{array}{l}\text { Rodriguez-Villalon et } \\
\text { al. } 2014\end{array}$ & $\mathrm{~N} / \mathrm{A}$ \\
\hline $\begin{array}{l}\text { BRX:BRX-CITRINE in smxl4-1 smxI5-1 } \\
\text { (SALK 037136, SALK 018522) }\end{array}$ & This paper & $\mathrm{N} / \mathrm{A}$ \\
\hline BAM3:BAM3- CITRINE in wild type & $\begin{array}{l}\text { Rodriguez-Villalon et } \\
\text { al. } 2014\end{array}$ & $\mathrm{~N} / \mathrm{A}$ \\
\hline $\begin{array}{l}\text { BAM3:BAM3-CITRINE in smxI4-1 smxI5-1 } \\
\text { (SALK_037136, SALK_018522) }\end{array}$ & This paper & $\mathrm{N} / \mathrm{A}$ \\
\hline CVP2:NLS-VENUS in wild type & $\begin{array}{l}\text { Rodriguez-Villalon et } \\
\text { al. } 2014\end{array}$ & $\mathrm{~N} / \mathrm{A}$ \\
\hline $\begin{array}{l}\text { CVP2:NLS-VENUS in smxl4-1 smxl5-1 } \\
\text { (SALK_037136, SALK_018522) }\end{array}$ & This paper & $\mathrm{N} / \mathrm{A}$ \\
\hline Nicotiana benthamiana & Karin Schumacher & $\mathrm{N} / \mathrm{A}$ \\
\hline $\begin{array}{l}\text { Saccharomyces cerevisiae: AH109 (MATa, trp1- } \\
\text { 901, leu2-3, 112, ura3-52, his3-200, gal4A, gal80 } 1 \text {, } \\
\text { LYS2 : : GAL1UAS-GAL1TATA-HIS3, GAL2UAS- } \\
\text { GAL2TATA-ADE2, URA3 : : MEL1UAS-MEL1 } \\
\text { TATA-lacZ) }\end{array}$ & $\begin{array}{l}\text { Armin Djamei } \\
\text { Matchmaker } \\
\text { Hybrid System } 3 \\
\text { (Clontech, Palo Alto) }\end{array}$ & $\begin{array}{l}\text { https://www.takara } \\
\text { bio.com/assets/do } \\
\text { cuments/User\%20 } \\
\text { Manual/PT3247- } \\
\text { 1.pdf }\end{array}$ \\
\hline \multicolumn{3}{|l|}{ Recombinant DNA } \\
\hline 35S:SMXL5-3XHA & This paper & pEW33 \\
\hline 35S:6xc-Myc-OBE3 & This paper & pEW78 \\
\hline 35S:OBE3-mGFP & This paper & $p V L 127$ \\
\hline 35S:SMXL5-mCherry & This paper & pVL122 \\
\hline UBI10:mGFP-mCherry-NLS & This paper & pCW194 \\
\hline 35S:mCherry-NLS & This paper & pMG103 \\
\hline SMXL5:OBE3-miRNA3 & This paper & pEW65 \\
\hline SMXL5:OBE3-miRNA4 & This paper & pEW66 \\
\hline SMXL4:SMXL4-YFP (+ 3' SMXL4 terminator) & Wallner et al. 2017 & pEW23 \\
\hline SMXL5:OBE3-turquoise & This paper & $p E W 72$ \\
\hline OPS:SMXL5-VENUS & This paper & pNT52 \\
\hline OPS:ER-VENUS & This paper & pNT53 \\
\hline BAM3:SMXL5-VENUS & This paper & pNT49 \\
\hline BAM3:ER-VENUS & This paper & pNT50 \\
\hline CVP2:SMXL5-VENUS & This paper & pNT16 \\
\hline
\end{tabular}




\begin{tabular}{|c|c|c|}
\hline CVP2:ER-VENUS & This paper & pNT69 \\
\hline APL:SMXL5-VENUS & This paper & pNT10 \\
\hline APL:ER-VENUS & This paper & pNT68 \\
\hline SMXL4:BRX-VENUS & This paper & pNT72 \\
\hline$B R X: B R X-C I T R I N E$ & $\begin{array}{l}\text { Rodriguez-Villalon et } \\
\text { al. } 2014\end{array}$ & $N / A$ \\
\hline \multicolumn{3}{|l|}{ Software } \\
\hline WMD3 - Web MicroRNA Designer Version 3 & $\begin{array}{l}\text { Max Planck Institute } \\
\text { for Developmental } \\
\text { Biology, Tübingen. }\end{array}$ & $\begin{array}{l}\text { http://www.weigelw } \\
\text { orld.org }\end{array}$ \\
\hline CLC Main Workbench 7.6.1 & $\begin{array}{l}\text { CLC Bio Qiagen, } \\
\text { Aarhus, Denmark }\end{array}$ & \\
\hline ImageJ $1.51 \mathrm{~h}$ & $\begin{array}{l}\text { National Institute of } \\
\text { Health, Bethesda, } \\
\text { USA }\end{array}$ & \\
\hline Microsoft Office 2016 & $\begin{array}{l}\text { Microsoft, Redmond, } \\
\text { USA }\end{array}$ & \\
\hline Adobe Creative Suite CS6 & $\begin{array}{l}\text { Adobe, San Jose, } \\
\text { USA }\end{array}$ & \\
\hline SPSS V. 25 & IBM, Armonk, USA & \\
\hline GraphPad Prism version 6.01 & $\begin{array}{l}\text { GraphPad Software, } \\
\text { La Jolla, USA }\end{array}$ & \\
\hline \multicolumn{3}{|l|}{ Other } \\
\hline Anti-HA MicroBeads & $\begin{array}{l}\text { Miltenyi Biotec, } \\
\text { Bergisch Gladbach, } \\
\text { Germany }\end{array}$ & Cat\#130-094-255 \\
\hline$\mu$ Columns & $\begin{array}{l}\text { Miltenyi Biotec, } \\
\text { Bergisch Gladbach, } \\
\text { Germany }\end{array}$ & Cat\#130-042-701 \\
\hline Advanced Fluorescence and ECL Imager & $\begin{array}{l}\text { Intas Science } \\
\text { Imaging } \\
\text { Instruments, } \\
\text { Göttingen, Germany }\end{array}$ & N/A \\
\hline Confocal microscope TCS SP5 & $\begin{array}{l}\text { Leica Microsystems; } \\
\text { Mannheim, } \\
\text { Germany }\end{array}$ & $\mathrm{N} / \mathrm{A}$ \\
\hline Confocal microscope TCS SP8 & $\begin{array}{l}\text { Leica Microsystems; } \\
\text { Mannheim, } \\
\text { Germany }\end{array}$ & $\mathrm{N} / \mathrm{A}$ \\
\hline
\end{tabular}

